\title{
The influence of occupational stress on workers' health: systematic review and meta-
}

\section{analysis}

\author{
Influência do estresse ocupacional na saúdle do trabalhador: Revisão sistemática e meta-análise \\ Influencia del estrés laboral en la salud de los trabajadores: Revisión sistemática y metanálisis
}

\author{
Lorene Gonçalves Coelho \\ ORCID: https://orcid.org/0000-0001-8305-7421 \\ Federal University of Recôncavo of Bahia, Brazil \\ E-mail: lorene.coelho@yahoo.com.br \\ Priscila Ribas de Farias Costa \\ ORCID: https://orcid.org/0000-0003-3809-9037 \\ Federal University of Bahia, Brazil \\ E-mail: priscilarf@yahoo.com.br \\ Sanjay Kinra \\ ORCID: https://orcid.org/0000-0001-6690-4625 \\ London School of Hygiene and Tropical Medicine, England \\ E-mail: sanjay.kinra@ishtm.ac.uk \\ Jacqueline Costa Dias Pitangueira \\ ORCID: https://orcid.org/0000-0002-3488-724X \\ Federal University of Recôncavo of Bahia, Brazil \\ E-mail: jack_cdias@hotmail.com \\ Carlos Rodrigo Nascimento de Lira \\ ORCID: https://orcid.org/0000-0001-7266-1367 \\ Federal University of Bahia, Brazil \\ E-mail: carlos.rodrigo.n@hotmail.com \\ Rita de Cássia Coelho de Almeida Akutsu \\ ORCID: https://orcid.org/0000-0003-0699-7617 \\ University of Brasília, Brazil \\ E-mail: rita_akutsu@yahoo.com.br
}

\begin{abstract}
Background/objective: This study is a systematic review and meta-analysis that aims to systematize and synthesize the results of observational studies which demonstrated the occupational stress influence in workers' health. Methods: The literature review was carried out through searches in PUBMED, WEB OF SCIENCE, EMBASE, SCOPUS, CINAHL, PSCYINFO, and LILACS databases, from July to October 2020, and updated in October 2021. Observational studies that considered occupational stress as exposure, accessed it by the Job Content Questionnaire, and evaluated its influence in workers' health were included, regardless of their publication year. The risk of bias of the included studies was assessed through the Research Triangle Institute Item Bank on Risk of Bias and Precision of Observational Studies. Results: For the qualitative analysis, the search strategy retained 42 studies, including 182187 participants. Among retained studies, the influence of occupational stress was examined in cardiovascular diseases (CVD) $(n=10)$, as primary outcome, and metabolic syndrome (MS) $(n=5)$, dyslipidemias $(n=15)$, and obesity $(n=22)$, as additional outcomes. Systematized evidence showed that high levels of occupational stress appear to be associated with CVD and MS. However, its influence in dyslipidemias and obesity remain unclear. Meta-analyses of these clinical conditions showed significant associations between occupational stress and CVD (OR 1.34; 95\%CI 1.15-1.57) and MS (OR 2.75, CI95\% 1.97-3.83), but no significant effect between stress at work and dyslipidemias and obesity. Conclusions: A consistent adverse effect of occupational stress was observed on CVD and MS, considering studies with high methodological quality (low risk of bias). These findings can contribute to the development of actions to attenuate the stress at work to provide a better quality of life for workers. Other: This work received no specific grant from any funding agency and was registered on the PROSPERO platform under the CDR protocol number 102751.

Keywords: Demand-control model; Obesity; Dyslipidemias; Metabolic syndrome; Cardiovascular diseases.
\end{abstract}

\section{Resumo}

Justificativa/objetivo: Este estudo é uma revisão sistemática e meta-análise que visa sistematizar e sintetizar os resultados de estudos observacionais que demonstraram a influência do estresse ocupacional na saúde do trabalhador. Métodos: A revisão da literatura foi realizada por meio de buscas nas bases de dados PUBMED, WEB OF SCIENCE, EMBASE, SCOPUS, CINAHL, PSCYINFO e LILACS, de julho a outubro de 2020, e atualizada em outubro de 2021. Estudos observacionais que consideraram o estresse ocupacional como exposição, acessados pelo Job Content 
Questionnaire, e avaliados sua influência na saúde do trabalhador foram incluídos, independente do ano de publicação. O risco de viés dos estudos incluídos foi avaliado por meio do Research Triangle Institute Item Bank on Risk of Bias and Precision of Observational Studies. Resultados: Para a análise qualitativa, a estratégia de busca reteve 42 estudos, incluindo 18.2187 participantes. Entre os estudos retidos, a influência do estresse ocupacional foi examinada em doenças cardiovasculares $(\mathrm{DCV})(\mathrm{n}=10)$, como desfecho primário, e síndrome metabólica $(\mathrm{SM})(\mathrm{n}=5)$, dislipidemias $(n=15)$ e obesidade $(n=22)$, como resultados adicionais. Evidências sistematizadas mostraram que altos níveis de estresse ocupacional parecem estar associados a DCV e SM. No entanto, sua influência nas dislipidemias e na obesidade permanece incerta. Meta-análises dessas condições clínicas mostraram associações significativas entre estresse ocupacional e DCV (OR 1,34; IC 95\% 1,15-1,57) e SM (OR 2,75, IC95\% 1,97-3,83), mas nenhum efeito significativo entre estresse no trabalho e dislipidemias e obesidade. Conclusão: Foi observado um efeito adverso consistente do estresse ocupacional sobre DCV e SM, considerando estudos com alta qualidade metodológica (baixo risco de viés). Esses achados podem contribuir para o desenvolvimento de ações de atenuação do estresse no trabalho para proporcionar uma melhor qualidade de vida aos trabalhadores. Outros: Este trabalho não recebeu financiamento específico de nenhuma agência financiadora e foi registrado na plataforma PROSPERO sob o protocolo CDR número 102751.

Palavras-chave: Modelo de controle de demanda; Obesidade; Dislipidemias; Síndrome metabólica; Doenças cardiovasculares.

\section{Resumen}

Justificación/objetivo: Este estudio es una revisión sistemática y un metanálisis que tiene como objetivo sistematizar y sintetizar los resultados de estudios observacionales que demostraron la influencia del estrés laboral en la salud de los trabajadores. Métodos: La revisión de la literatura se realizó a través de búsquedas en las bases de datos PUBMED, WEB OF SCIENCE, EMBASE, SCOPUS, CINAHL, PSCYINFO y LILACS, de julio a octubre de 2020, y actualizada en octubre de 2021. Estudios observacionales que consideraron el estrés laboral como exposición, se accedió a él mediante el Cuestionario de Contenido Laboral, y se evaluó su influencia en la salud de los trabajadores, independientemente del año de publicación. El riesgo de sesgo de los estudios incluidos se evaluó a través del banco de artículos sobre riesgo de sesgo y precisión de los estudios observacionales del Research Triangle Institute. Resultados: Para el análisis cualitativo, la estrategia de búsqueda retuvo 42 estudios, incluidos 182187 participantes. Entre los estudios retenidos, se examinó la influencia del estrés laboral en las enfermedades cardiovasculares (ECV) $(\mathrm{n}=10)$, como resultado primario, y el síndrome metabólico $(\mathrm{SM})(\mathrm{n}=5)$, las dislipidemias $(\mathrm{n}=15)$ y la obesidad $(\mathrm{n}=22)$, como resultados adicionales. La evidencia sistematizada mostró que los altos niveles de estrés ocupacional parecen estar asociados con ECV y EM. Sin embargo, su influencia en las dislipidemias y la obesidad sigue sin estar clara. Los metanálisis de estas condiciones clínicas mostraron asociaciones significativas entre estrés laboral y ECV (OR 1,34; IC95\% 1,15-1,57) y SM (OR 2,75, IC95\% 1,97-3,83), pero ningún efecto significativo entre estrés laboral y dislipidemias y obesidad. Conclusiones: Se observó un efecto adverso consistente del estrés laboral sobre ECV y SM, considerando estudios con alta calidad metodológica (bajo riesgo de sesgo). Estos hallazgos pueden contribuir al desarrollo de acciones para atenuar el estrés en el trabajo para brindar una mejor calidad de vida a los trabajadores. Otro: Este trabajo no recibió subvención específica de ninguna agencia financiadora y fue registrado en la plataforma PROSPERO bajo el número de protocolo CDR 102751.

Palabras clave: Modelo de control de la demanda; Obesidad; Dislipidemias; Síndrome metabólico; Enfermedades cardiovasculares.

\section{Introduction}

Work plays an important role in individuals' socioeconomic life and provides social identity, self-esteem, personal growth, and regular income (Filha et al., 2013). Nevertheless, it has become a major public health concern, due to occupational stress (Silva \& Guimarães, 2016).

Occupational stress can be understood as a complex process in which workers seek to respond to demands that go beyond the possibilities of individual and social adaptation, triggering disorders at a biological and/or behavioral level (Sousa \& Araújo, 2015).

As a result of growing job market competitiveness, individuals have experienced this process, since they have been increasingly committed to job demands, and faced difficulties in reconciling these with their personal life, which may result in physical and psychosocial distress and multiple diseases (Sousa \& Araújo, 2015), as described in a number of studies.

Santos, Vargas and Reis (2014) verified a degree of stress in $61.4 \%$ of community health workers studied in Aracaju, Sergipe, Brazil; Souza and Araújo (2015) identified occupational stress with a risk of illness in $71.2 \%$ of health professionals at 
a university hospital in the Brazilian midwest region; and Sancini et al. (2017) found associations between job stress and increased blood glucose levels in workers at an Italian company. In addition, other authors also identified positive associations between occupational stress and cardiovascular disease and its risk factors, anxiety, depression, and dissatisfaction with their own health (Filha et al., 2013; Silva \& Guimarães, 2016; Araújo et al., 2003; Tonini et al., 2013; Juvanhol et al., 2017; Creedy et al., 2017).

Due to this growing accumulation of evidence associating the stress at work and the risk of illness, especially when involving cardiovascular diseases, the main cause of morbidity and mortality in several countries, it becomes fundamental to perform studies that aim to understand this relation in a theoretical referential area, reinforcing the need of deepening the investigations to a better understanding of the illness phenomenon in the occupational stress interface.

Thus, workers' healthcare must include an assessment of occupational stress and its consequences, especially in the current social system, where most of the population depends on its workforce as a guarantee for subsistence. This is important because diseases represent a double threat, since they affect both individuals' health and their productive capacity (Tonini et al., 2013).

Therefore, this systematic review and meta-analysis systematizes and synthesizes the results of observational studies which demonstrated the influence of occupational stress on workers' health.

\section{Methodology}

The systematic review was carried out according to the guidelines of the Preferred Reporting Items for Systematic reviews and Meta-Analyzes - PRISMA (Page et al., 2021), and was registered on the PROSPERO platform (York University) under CRD protocol number 102751, evaluating the influence of occupational stress on worker's health. The acronym PECR was used to structure the research question for this study: Population (adult workers), Exposure (occupational stress), Comparison (low level or lack of occupational stress), and Result (chronic diseases, including obesity, dyslipidemias, hypertension, diabetes mellitus, and cardiovascular diseases).

The eligible studies had to meet all of the following criteria: 1) adult workers aged between 18 and 60;2) observational studies (cross-sectional, case-control, and cohort studies); 3) original studies; 4) studies that assessed occupational stress as exposure, and through the Job Content Questionnaire (JCQ); 5) reported its relationship to workers' health; related to chronic diseases; 6) and published in any language. We excluded interventional studies, reviews, metaanalyses, editorials, letters to authors, replies; studies composed by individuals under the age of 18, or over 60; and studies in which occupational stress was not the focus of the evaluation, and was assessed by other instruments. Detailed inclusion and exclusion criteria are listed in Table 1. 
Table 1. Inclusion and exclusion criteria for the observational studies selection.

\begin{tabular}{lll}
\hline Criteria & Included & Not included \\
\hline $\begin{array}{l}\text { Study type } \\
\text { Type of publication }\end{array}$ & $\begin{array}{l}\text { Observational } \\
\text { Original studies }\end{array}$ & $\begin{array}{l}\text { Interventional } \\
\text { Reviews, meta-analyses, editorials, letters to authors, } \\
\text { replies }\end{array}$ \\
$\begin{array}{l}\text { Year of publication } \\
\text { Language }\end{array}$ & All & - \\
$\begin{array}{l}\text { Sample } \\
\text { characteristics }\end{array}$ & All & - \\
Exposure & Samples containing adult workers aged 18-60 & $\begin{array}{l}\text { Samples composed of individuals aged under 18, or } \\
\text { over 60 }\end{array}$ \\
Outcomes & $\begin{array}{l}\text { Occupational stress as exposure and assess using the } \\
\text { Job Content Questionnaire (JCQ) }\end{array}$ & $\begin{array}{l}\text { Occupational stress is not the focus of the study } \\
\text { evaluation and assess using other instruments } \\
\text { Chronic diseases, including obesity, dyslipidemias, } \\
\text { hypertension, diabetes mellitus, and cardiovascular } \\
\text { diseases }\end{array}$ \\
\hline
\end{tabular}

Source: Own authorship.

\section{Search strategy}

A literature review was conducted through research on the Medical Literature and Retrivial System on Line (MEDLINE) via PubMed, WEB OF SCIENCE, Excerpta Medica Database (EMBASE), SCOPUS, Cumulative Index to Nursing and Allied Health Literature (CINAHL), PSCYINFO and Latin American and Caribbean Health Sciences Literature (LILACS) databases, from July to October 2020 by two independents reviewers, and updated in October 2021.

High sensibility research strategies were used, including search terms that described the exposure and outcomes, in accordance with the Medical Subject Heading (MeSH), Health Sciences Descriptors (DeCS) and Embase (EMTREE) subject heading descriptors, exploring all trees: "Occupational Stress", or "Job Stress", or "Work Related Stress", or "Work Place Stress", or "Professional Stress", or "Job Related Stress" and "Obesity", or "Overweight", or "Body Weight", or "Abdominal Obesity", or "Central Obesity", or "Visceral Obesity", or "Severe Obesity", or "Morbid Obesity" and "Hypertension", or "High Blood Pressure", or "Systolic Blood Pressure", or "Diastolic Blood Pressure", or "Arterial Hypertension", or "Cardiovascular Hypertension", or "Hypertensive Disease", or "Systemic Hypertension" and "Dyslipidemia", or "Dyslipoproteinemia", or "Hypercholesterolemia", or "Hyperlipoproteinemia", or "Hypertriglyceridemia" and "Diabetes mellitus", or "diabetes", or "diabetic", or "non-insulin dependent diabetes mellitus", or "diabetes mellitus type 2", or "DM 2", or "insulin independent diabetes mellitus", or "NIDDM", or "T2DM" and "Cardiovascular Disease", or "Myocardial Ischemia", or "Ischemic Heart Disease", or "Myocardial Infarction", or "Cardiovascular Stroke", or "Myocardial Infarct", or "Heart Attack". Additionally, complementary searches were carried out through active searches of the bibliographic references of the studies included in the review. There were no language restrictions, or delimitations for the year the studies were published.

The search strategies retrieved 31,930 articles, the abstracts were pooled, and imported into the online version of Covidence ${ }^{\circledR}$, a systematic review management program. The reviewers independently decided which studies would be considered for data synthesis, according to the inclusion and exclusion criteria displayed in Table 1. Disagreements between the reviewers during the selection process were solved through discussion with a third reviewer.

Regarding this review's update, 1889 articles were retrieved, which were treated following the same protocol procedures as the ones in the initial research. Figure 1 illustrates the study selection process considering both searches.

\section{Data extraction and quality assessment}

For each original study selected for the final list, the researchers downloaded and evaluated the entire publication, and 
extracted the following data into Covidence ${ }^{\circledR}$, to assess quality and summarize the evidence: study characteristics (author, year of publication, design, location, composition and sample size); participants' characteristics (average age, gender, and type of occupation); exposure; outcome details (type of chronic disease, measurement method, and diagnostic criteria); limitations and main conclusions.

With regards to the outcomes, the results presented for cardiovascular diseases (as primary outcome), hypertension, diabetes mellitus, metabolic syndrome, dyslipidemias and obesity (as additional outcomes) were included, considering the variety of diagnostic criteria and their cut-off points, if they were widely recognized by the scientific community. With regards to exposure, occupational stress was considered when assessed by the JCQ, and classified according to the Demand-Control Model (Karasek, 1979). All disagreements on selecting and extracting the data were resolved through discussions with a third reviewer. When any of the cited data was absent, we were unable to contact the authors.

In order to determine the quality of the selected studies, an assessment of risk of bias was conducted by two independent reviewers, who used the Research Triangle Institute (RTI) Item Bank on Risk of Bias and Precision of Observational Studies, a validated reference published by Viswanathan and Berkman (2012). These authors provide instructions on how to use the RTI, and its items, in accordance with the different study designs under assessment. Considering their recommendation, and the type of studies selected for this review, twelve items to assess cross-sectional studies (inclusion/exclusion criteria, recruitment strategy, selection of the comparison group, blinding of outcome assessor, and measure validation), and fifteen for cohort studies (three additional questions about study length and the impact of losses during follow-up) were applied. Cross-sectional studies with four or more items rated as negative or unclear could not be considered as low risk of bias. In a similar way, cohort studies with five or more negative, or unclear items, were rated potentially biased studies.

\section{Statistical analysis}

For combined studies (Deeks et al., 2019; Higgins et al., 2021), quantitative data synthesis was performed using metaanalysis. Thus, meta-analysis was performed to assess the association between occupational stress and the outcomes of interest: cardiovascular diseases (CVD), metabolic syndrome (MS), dyslipidemias, and obesity according body mass index (BMI) and waist circumference (WC).

The heterogeneity extension of the meta-analyses was tested using the Cochran $\mathrm{Q}$ test and quantified by the inconsistency test $\left(\mathrm{I}^{2}\right.$ statistic). This statistic determines the magnitude of heterogeneity by the proportion of total variation between studies due to heterogeneity (Deeks et al., 2019; Higgins et al., 2021). A p-value is often cited as an indication of the extent of variability between studies. Thus, the chi-square test was used to assess the significance of heterogeneity. For this purpose, a significance level of $\mathrm{p}<0.10$ was used, in order to detect the true heterogeneity between the results of the studies (Deeks et al., 2019; Higgins et al., 2021).

The magnitude of heterogeneity was identified by calculating the $\mathrm{I}^{2}$, which ranges from 0 to $100 \%$. Thereby, an $\mathrm{I}^{2}$ close to zero suggests that the entire dispersion can be attributed to the study's random error, that is, there is no heterogeneity. If an $\mathrm{I}^{2}$ value close to $25 \%$ is calculated, it indicates low heterogeneity between studies; higher than $50 \%$ indicates moderate, and above 75\% high heterogeneity (Deeks et al., 2019; Higgins et al., 2021).

The original studies included in this review used different statistical analyses to assess the association between occupational stress and the outcomes of interest, justifying the performance of separate meta-analyses for each outcome. In order to assess the relationship between occupational stress, CVD, MS, BMI, and WC, meta-analyses of the association measure the Odds Ratio (OR) reported in the respective original articles, and their confidence intervals were converted into standard errors. For the studies that calculated the Hazard Ratio (HR), considering the assumption that the HR is 
asymptotically similar to the Relative Risk (RR) (Rothman; Greenland \& Lash, 2008), it was converted into the OR using the calculation proposed by Grant (2014).

In order to combine the results of studies evaluating the relationship between occupational stress and dyslipidemias, two meta-analyses were performed: one using the OR reported in the original articles as a common measure of comparison, with its confidence intervals converted into standard errors. If the study presented the HR instead of the OR, the assumption that the HR is asymptotically similar to the RR, then converted into the OR (Grant, 2014) was also considered; and another using the beta coefficients of the linear regression models as a measure of association, and their respective standard errors.

For all meta-analyses, the metan command was used with the specification of two variables, if the measure of effect (or beta coefficient), and its respective standard errors, were transformed into a logarithmic scale, to stabilize the variances and normalize the distributions. The eform option was specified to convert the summary measure to the normal scale, favoring its interpretability (Deeks et al.,2019; Higgins et al., 2021). In the case of moderate to high heterogeneity, the effect measure grouping was calculated using random-effects models by the restricted maximum likelihood (REML) method. In a case of low heterogeneity, REML models were also used, since, in these cases, the results of meta-analyses using random-effects or fixedeffects models, are the same.

Publication bias was assessed using the Egger test and funnel graph for CVD and BMI meta-analyses, to which a minimum number of ten articles were included (Deeks et al., 2019; Higgins et al., 2021). Sensitivity analysis was performed by removing studies with discrepant results for each outcome. When applicable, a subgroup analysis was performed according to the study design variable.

Statistical analysis was performed using STATA for MAC statistical software (Version 16.0, Stata Corp LP, College Station).

\section{Results}

\section{Study selection}

The searches resulted in 33,819 studies. Of these, 33,803 were retrieved through search strategies on the databases, and 16 manually. Following duplication screening, 12,913 studies were excluded, and a further 20,529 were excluded, based on their title and abstract content. A full-text examination of 377 studies excluded 292 studies, resulting in 85 eligible studies.

During the screening process, we also assessed the systematic reviews and meta-analyses retrieved in our searches, to verify if other authors had published work on the same exposure, and some of our interesting outcomes. Gilbert-Ouimet et al. (2014) and Siu et al. (2016) had already published on occupational stress (Demand-Control Model), hypertension and diabetes mellitus, respectively. Thus, these two outcomes were excluded from this review.

Therefore, 42 studies were included for qualitative and quantitative analysis. The final number of quantitative studies for each outcome is shown in Figure 1, highlighting that a single study may offer one or more outcome results of interest in this review.

The selected studies were published between 1991 and 2021. Regarding study location, eleven were performed in America, ten in Asia, eighteen in Europe, one in Middle East, one in Oceania, and one was multicentre. Twenty were crosssectional studies and twenty-two were prospective cohorts. The number of subjects varied from 68 to 21419 . Thirty studies recruited both men and women, nine consisted of men only, and three consisted of women only. All studies used the Karasek's JCQ to assess occupational stress. Overall, ten reported results on the relationship between occupational stress and cardiovascular diseases, five on metabolic syndrome, fifteen on dyslipidemias, and twenty-two on obesity. The main characteristics of the retrieved studies and the assessment of risk of bias are described in Table 2 and 3. 


\section{Primary outcome}

Cardiovascular diseases. Ten studies included in this systematic review tested the influence of occupational stress on the risk of non-fatal CVD. In their study with bus drivers, Chen et al. (2018) verified that in terms of high job stress, the risk for the incidence of CVD was not significantly increased among drivers with high job stress (HR 1.20, 95\%CI 0.67-2.14), when compared with those with low job stress. This lack of association was also observed by Smith et al. (2021) (HR 0.92, 95\%CI 0.46-1.84 for women, and HR 0.75, 95\%CI 0.44-1.27 for men).

Bosma et al. (1998) nor De Baquer et al. (2005) found positive associations between job strain and the incidence of CVD. However, Bosma et al. (1998) identified low job control as a strong predictor of new disease cases (OR 1.63, 95\%CI 1.16-2.28), in contrast to Hwang et al. (2010), who observed that job control was not a predictor of the risk of CVD (Beta $0.020 ; \mathrm{p}>0.05)$.

Pelfrene et al. (2003) verified that high strain, active and passive work exposures, in comparison to low strain work, did not indicate a significant association with high CVD risk in Belgian workers. Similarly, Wu et al. (2019) did not identify an association between occupational stress and the risk of CVD in Thai drivers (HR 1.14, 95\%CI 0.68-1.90).

On the other hand, Kivimaki et al. (2007) observed that job strain was associated with an increased incidence of CVD (OR 1.36, 95\%CI 1.07-1.72) in civil servants in the United Kingdom, as did Power et al. (2020) in female workers form Canada (HR 1.85, 95\%CI 1.19-2.90). And Muniz et al. (2019), considering low strain as a reference group, demonstrated that workers classified as active and passive high strain, had a non-significant increase in the chances of having poor CV health. 
Research, Society and Development, v. 11, n. 3, e23111326449, 2022

(CC BY 4.0) | ISSN 2525-3409 | DOI: http://dx.doi.org/10.33448/rsd-v11i3.26449

Figure 1. Flow diagram of the study selection process (adapted from PRISMA).
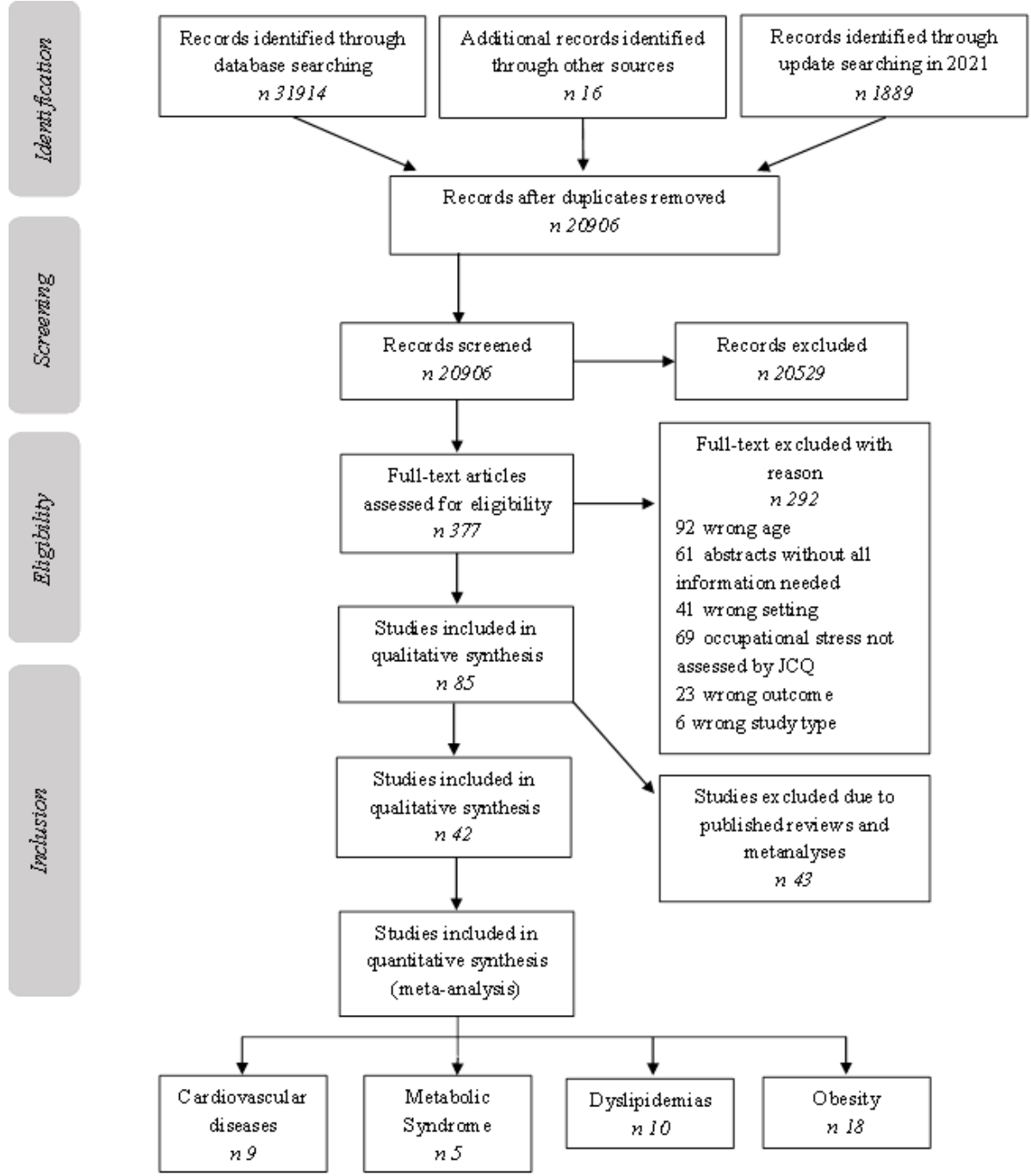

Source: Own authorship. 
Research, Society and Development, v. 11, n. 3, e23111326449, 2022

(CC BY 4.0) | ISSN 2525-3409 | DOI: http://dx.doi.org/10.33448/rsd-v11i3.26449

Table 2. Qualitative analysis of cohort and cross-sectional studies of occupational stress the primary outcome (cardiovascular diseases).

\begin{tabular}{|c|c|c|c|c|c|c|c|c|}
\hline References & Country & Language & Study type & $\begin{array}{l}\text { Sample } \\
\text { size }\end{array}$ & Sex & $\begin{array}{l}\text { Age (years) } \\
\text { Range or Mean } \\
\text { (SD) }\end{array}$ & Worker type & $\begin{array}{l}\text { Risk of bias } \\
\text { (points) }\end{array}$ \\
\hline Bosma et al. (1998) & $\begin{array}{l}\text { United } \\
\text { Kingdom }\end{array}$ & English & Cohort & 10308 & $\mathrm{M} / \mathrm{F}^{*}$ & $35-55$ & Civil servants & Low (14) \\
\hline Chen et al. (2018) & Taiwan & English & Cohort & 707 & M & $43.5(6.90)$ & Drivers & Low (14) \\
\hline DeBacquer et al. (2005) & Belgium & English & Cohort & 14337 & M & $43.80(6.00)$ & Industrial / Admin ${ }^{\star}$ workers & Low (13) \\
\hline Hwang et al. (2010) & $\begin{array}{l}\text { South Korea } \\
\text { United }\end{array}$ & English & Cross-sectional & 238 & $\mathrm{M} / \mathrm{F}$ & $19-58$ & Blue-collar workers & Low (12) \\
\hline Kivimaki et al. (2007) & Kingdom & English & Cohort & 8086 & $\mathrm{M} / \mathrm{F}$ & $35-55$ & Civil servants & Low (14) \\
\hline Muniz et al. (2019) & Brazil & Portuguese & Cross-sectional & 478 & $\mathrm{M} / \mathrm{F}$ & $44.30(12.00)$ & Civil servants / professors & Present (8) \\
\hline Pelfrene et al. (2003) & Belgium & English & Cross-sectional & 19718 & $\mathrm{M} / \mathrm{F}$ & $35-59$ & Various & Low (12) \\
\hline Power et al. (2020) & Canada & English & Cohort & 8073 & $\mathrm{M} / \mathrm{F}$ & $\begin{array}{l}49.5(4.90) \\
\text { With } C V D^{\dagger} 50.8(-)\end{array}$ & Not provided & Low (13) \\
\hline Smith et al. (2021) & Canada & English & Cohort & 13291 & $\mathrm{M} / \mathrm{F}$ & $\begin{array}{l}\text { Without } C V D 45.5 \\
(-)\end{array}$ & Not provided & Low (13) \\
\hline Wu et al. (2009) & Taiwan & English & Cohort & 916 & M & $<35->50$ & Drivers & Low (13) \\
\hline
\end{tabular}

$*$ M: Male. F: Female. ${ }^{\dagger} C V D$ : Cardiovascular diseases. ${ }^{*}$ Admin: Administrative. Source: Own authorship. 
Table 3. Qualitative analysis of cohort and cross-sectional studies of occupational stress and the additional outcomes.

\begin{tabular}{|c|c|c|c|c|c|c|c|c|}
\hline References & Country & Language & Study type & $\begin{array}{c}\text { Sample } \\
\text { size } \\
\end{array}$ & Sex & $\begin{array}{l}\text { Age (years) } \\
\text { Range or Mean (SD) }\end{array}$ & Worker type & $\begin{array}{l}\text { Risk of } \\
\text { bias } \\
\text { (points) }\end{array}$ \\
\hline \multicolumn{9}{|l|}{ Metabolic syndrome } \\
\hline Chandola et al. (2006) & $\begin{array}{l}\text { United } \\
\text { Kingdom }\end{array}$ & English & Cohort & 7034 & $\mathrm{M} / \mathrm{F}^{*}$ & $35-56$ & Civil servants & Low (14) \\
\hline Edwards et al. (2012) & USA & English & Cohort & 2966 & $\mathrm{M} / \mathrm{F}$ & $18-30$ & Not provided & Low (13) \\
\hline Garbarino et al. (2015) & Italy & English & Cohort & 234 & M & $41.00(7.40)$ & Police officers & Low (11) \\
\hline Kang et al. (2004) & South Korea & English & Cross-sectional & 169 & M & $>40$ & Blue-collar workers & Present (7) \\
\hline Magnavita \& Fileni (2014) & Italy & English & Cross-sectional & 654 & $\mathrm{M} / \mathrm{F}$ & $<45->55$ & Radiologists & Present (5) \\
\hline \multicolumn{9}{|l|}{ Dyslipidemias } \\
\hline Aboa-Éboulé et al. (2007) & Canada & English & Cohort & 972 & $\mathrm{M} / \mathrm{F}$ & $35-59$ & Not provided & Low (13) \\
\hline Cho et al. (2005) & South Korea & English & Cross-sectional & 216 & M & $42.48(7.37)$ & Aircrew & Present (7) \\
\hline Evolahti (2009) & Sweden & English & Cohort & 396 & $\mathrm{~F}$ & $49-53$ & Admin ${ }^{*}$ workers & Present (10) \\
\hline Garbarino et al. (2015) & Italy & English & Cohort & 234 & M & $41.00(7.40)$ & Police officers & Low (11) \\
\hline Greenlund et al. (1995) & USA & English & Cohort & 2665 & $\mathrm{M} / \mathrm{F}$ & $18-30$ & Various & Low (13) \\
\hline Kang et al. (2005) & South Korea & English & Cross-sectional & 152 & M & $20-57$ & Various & Low (10) \\
\hline Kawakami et al. (1998) & Japan & English & Cross-sectional & 2882 & M & $\begin{array}{l}\text { Day } W^{\dagger} 38.10(9.40) \\
\text { Shift } W 38.40(8.50)\end{array}$ & Electrical workers & Low (11) \\
\hline Li et al. (2007) & China & English & Cross-sectional & 504 & $\mathrm{M} / \mathrm{F}$ & $37.94(9.47)$ & $\begin{array}{l}\text { lndustrial workers } \\
\text { Civil servants / }\end{array}$ & Low (10) \\
\hline Muniz et al. (2019) & Brazil & Portuguese & Cross-sectional & 478 & $\mathrm{M} / \mathrm{F}$ & $44.30(12.00)$ & professors & Present (8) \\
\hline Netterstrom et al. (1991) & Denmark & English & Cross-sectional & 1504 & $\mathrm{M} / \mathrm{F}$ & $30-60$ & Various & Low (11) \\
\hline Neidhammer et al. (1998) & France & English & Cohort & 13226 & $\mathrm{M} / \mathrm{F}$ & $\begin{array}{l}\text { Male 47-56 } \\
\text { Female 42-56 }\end{array}$ & Electrical workers & Present (9) \\
\hline Pelfrene et al. (2002) & Belgium & English & Cohort & 21419 & $\mathrm{M} / \mathrm{F}$ & $35-59$ & Various & Low (13) \\
\hline Peter et al. (2002) & Sweden & English & Cross-sectional & 2099 & $\mathrm{M} / \mathrm{F}$ & $30-55$ & Not provided & Low (10) \\
\hline Riese et al. (2000) & Netherlands & English & Cross-sectional & 165 & $\mathrm{~F}$ & $22-55$ & Nurses & Low (10) \\
\hline Shirom et al. (2009) & Israel & English & Cohort & 1137 & $\mathrm{M} / \mathrm{F}$ & $\begin{array}{l}\text { Male } 46.66(9.63) \\
\text { Female } 47.18(8.84)\end{array}$ & Not provided & Low (13) \\
\hline
\end{tabular}




\begin{tabular}{|c|c|c|c|c|c|c|c|c|}
\hline References & Country & Language & Study type & $\begin{array}{l}\text { Sample } \\
\text { size }\end{array}$ & Sex & $\begin{array}{l}\text { Age (years) } \\
\text { Range or Mean } \\
\text { (SD) }\end{array}$ & Worker type & $\begin{array}{l}\text { Risk of } \\
\text { bias } \\
\text { (points) }\end{array}$ \\
\hline \multicolumn{9}{|l|}{ Obesity } \\
\hline Aboa-Éboulé et al. (2007) & Canada & English & Cohort & 972 & $\mathrm{M} / \mathrm{F}$ & $35-59$ & Not provided & Low (13) \\
\hline Armenta-Hernandez et al. (2020) & Mexico & English & Cross-sectional & 255 & $\mathrm{M} / \mathrm{F}$ & $31-40$ & Manufacturing workers & Present (8) \\
\hline Armenta-Hernandez et al. (2021) & Mexico & English & Cross-sectional & 170 & $\mathrm{M} / \mathrm{F}$ & $18-60$ & Manufacturing workers & Present (8) \\
\hline Berset et al. (2011) & Switzerland & English & Cohort & 68 & $\mathrm{M} / \mathrm{F}$ & $41.89(9.13)$ & Serving workers & Present (8) \\
\hline Brunner et al. (2007) & $\begin{array}{l}\text { United } \\
\text { Kingdom }\end{array}$ & English & Cohort & 10308 & $\mathrm{M} / \mathrm{F}$ & $35-55$ & Civil servants & Low (14) \\
\hline Garbarino et al. (2015) & Italy & English & Cohort & 234 & M & $41.00(7.40)$ & Police officers & Low (11) \\
\hline Hellerstedy \& Jeffery (1997) & USA & English & Cross-sectional & 3843 & $\mathrm{M} / \mathrm{F}$ & $\begin{array}{l}\text { Male } 39.00(0.20) \\
\text { Female } 37.00(0.20)\end{array}$ & Blue-collar / Admin workers & Low (11) \\
\hline Ishizaki et al. (2004) & Japan & English & Cross-sectional & 6676 & $\mathrm{M} / \mathrm{F}$ & $20-58$ & Metallurgic workers & Low (12) \\
\hline Ishizaki et al. (2008) & Japan & English & Cohort & 3571 & $\mathrm{M} / \mathrm{F}$ & $30-53$ & Metallurgic workers & Low (13) \\
\hline Jaaskelainen et al. (2015) & Finland & English & Cross-sectional & 4275 & $\mathrm{M} / \mathrm{F}$ & $31(-)$ & Not provided & Low (11) \\
\hline Lallukka et al. (2008) & Multicentre* & English & Cross-sectional & 11680 & $\mathrm{M} / \mathrm{F}$ & $40-60$ & White-collar workers & Low (12) \\
\hline Landsbergis et al. (1998) & USA & English & Cohort & 285 & $\mathrm{M} / \mathrm{F}$ & $30-60$ & Various & Low (13) \\
\hline Li et al. (2007) & China & English & Cross-sectional & 504 & $\mathrm{M} / \mathrm{F}$ & $37.94(9.47)$ & Industrial workers & Low (10) \\
\hline Muniz et al. (2019) & Brazil & Portuguese & Cross-sectional & 478 & $\mathrm{M} / \mathrm{F}$ & $44.30(12.00)$ & Civil servants / professors & Present (8) \\
\hline Netterstrom et al. (1991) & Denmark & English & Cross-sectional & 1504 & $\mathrm{M} / \mathrm{F}$ & $30-60$ & Various & Low (11) \\
\hline Neidhammer et al. (1998) & France & English & Cohort & 13226 & $\mathrm{M} / \mathrm{F}$ & $\begin{array}{l}\text { Male 47-56 } \\
\text { Female 42-56 }\end{array}$ & Electrical workers & Present (9) \\
\hline Niskanen et al. (2017) & Finland & English & Cohort & 4369 & $\mathrm{M} / \mathrm{F}$ & $40-60$ & & Low (11) \\
\hline Nomura et al. (2005) & Japan & English & Cross-sectional & 437 & $\mathrm{M}$ & 24-39 & Blue-collar / Admin workers & Low (10) \\
\hline Ostry et al. (2006) & Australia & English & Cross-sectional & 1050 & $\mathrm{M} / \mathrm{F}$ & $<30->51$ & White / Blue-collar workers & Low (10) \\
\hline Pelfrene et al. (2002) & Belgium & English & Cohort & 21419 & $\mathrm{M} / \mathrm{F}$ & $35-59$ & Various & Low (13) \\
\hline Riese et al. (2000) & Netherlands & English & Cross-sectional & 165 & $\mathrm{~F}$ & $22-55$ & Nurses & Low (10) \\
\hline Silva et al. (2021) & Brazil & English & Cross-sectional & 420 & $\mathrm{~F}$ & $18-59$ & Industrial workers & Low (10) \\
\hline
\end{tabular}

*M: Male. F: Female. ${ }^{\dagger} W$ : Workers. ${ }^{\star} A d m i n$ : Administrative. Source: Own authorship. 


\section{Additional outcomes}

Metabolic syndrome. Assessments of MS and its association with occupational stress were tested in five studies. Four of them found that individuals with stress at work had more chances to have the syndrome than those without or with lower levels of work stress (Chandola et al., 2006; Garbarino \& Magnavita, 2015; Magnavita \& Fileni, 2014; Edwards et al., 2012). Only Kang et al. (2005) did not find a significant difference between occupational stress and MS.

Dyslipidemias. The association between occupational stress and serum lipids (total cholesterol, LDL-cholesterol, HDL-cholesterol, and triglyceride) was identified in fifteen studies. Seven of these studies did not identify significant associations between any kind of dyslipidemias and job strain, job demands or job control (Muniz et al., 2019; Netterstrom et al., 1991; Greenlund et al., 1995; Kawakami et al., 1998; Riese et al., 2000; Cho et al., 2005; Aboa-Éboulé et al., 2007). On the other hand, Pelfrene et al. (2002) and Kang et al. (2004) demonstrated positive associations between stress at work and total cholesterol. Only Evolathi (2012) identified that control at work was a significant predictor of higher HDL-cholesterol, and Peter et al. (2002) that job strain was associated with elevated LDL-cholesterol. Neidhammer et al. (1998), Li et al. (2007)], Shirom et al. (2009), and Garbarino et al. (2015) verified positive associations between job stain, job demands and/or job control and serum triglyceride.

Obesity. Twenty-two studies included in this systematic review tested the influence of occupational stress on obesity. Twenty of these assessed obesity through BMI. Most of these studies did not identify significant associations between obesity and job strain (Riese et al., 2000; Aboa-Éboulé et al., 2007; Niedhammer et al., 1998; Landsbergis et al., 1998; Nomura et al., 2005; Ishizaki et al., 2008; Lallukka et al., 2008; Berset et al., 2011), or any job dimensions (Berset et al., 2011; Ishizaki et al., 2004). However, Netterstrom et al. (1991), Hellerstedt and Jeffery (1997), Ostry et al. (2006), Brunner et al. (2007), Li et al. (2007), Niskanen et al. (2017), Muniz et al. (2019), and Silva et al. (2021) identified that job strain, as well as job dimensions, were associated with poor BMI. In contrast, Pelfrene et al. (2002) and Armenta-Hernandez et al. $(2020 ; 2021)$ observed that the job dimensions were related to a reduction in BMI. Finally, five studies assessed obesity through WC. Brunner et al. (2007) and Ishizaki et al. (2008) identified that job stress was related to central obesity. Ishizaki et al. (2004) and Jääskeläinen et al. (2015) observed that the job dimensions were significantly associated with increased WC. In contrast, Garbarino et al. (2015) did not verify a significant association between work-related stress and central obesity.

\section{Meta-analyses of occupational stress and cardiovascular diseases, metabolic syndrome, dyslipidemias, and obesity}

The meta-analysis results of occupational stress, CVD, SM, dyslipidemias, and obesity (BMI and WC) are detailed below.

Cardiovascular diseases. In the meta-analysis of this outcome, which includes nine studies, a $34 \%$ greater chance of workers with high occupational stress levels having CVD was identified, when compared to those with low stress (OR 1.34; 95\%CI 1.15-1.57; $\mathrm{I}^{2}$ 0.00\%) (Figure 2). After removing the Hwang et al. (2010) and Muniz et al. (2019) studies, only retaining the cohort studies in the meta-analysis, there was no significant change in the measure of association (OR 1.35; 95\% CI 1.14$1.60 ; \mathrm{I}^{2} 20.31 \%$ (Figure 3). There was no evidence of effect of small studies in the meta-analysis, indicating an absence of publication bias (Egger's test p: 0.7996). 
Figure 2. Meta-analysis of observational studies on occupational stress and cardiovascular diseases.

\begin{tabular}{|c|c|c|c|c|c|}
\hline Study & Year & Country & Study Design & $\begin{array}{c}\text { OR } \\
\text { with } 95 \% \mathrm{Cl}\end{array}$ & $\begin{array}{c}\text { Weight } \\
(\%)\end{array}$ \\
\hline Muniz et al & 2019 & Brazil & Cross-sectional & $1.67[0.63,4.43]$ & 2.53 \\
\hline Hwang & 2010 & South Korea & Cross-sectional - & $1.02[0.48,2.16]$ & 4.17 \\
\hline Wu et al & 2019 & Taiwan & Cohort & $1.21[0.72,2.04]$ & 8.25 \\
\hline Bosma et al & 1998 & United Kingdom & Cohort & $1.63[1.16,2.29]$ & 16.91 \\
\hline De Bacquer & 2005 & Belgium & Cohort & $1.52[0.86,2.70]$ & 6.94 \\
\hline Chen et al & 2018 & Taiwan & Cohort & $1.19[0.67,2.14]$ & 6.71 \\
\hline Kivimaki et al & 2007 & United Kingdom & Cohort & $1.41[1.08,1.84]$ & 23.71 \\
\hline Smith et al & 2020 & Canada & Cohort & $0.85[0.56,1.30]$ & 11.84 \\
\hline Power et al (male) & 2020 & Canada & Cohort & $1.25[0.79,1.98]$ & 10.11 \\
\hline Power et al (female) & 2020 & Canada & Cohort & $1.95[1.18,3.21]$ & 8.81 \\
\hline Overall & & & & $1.34[1.15,1.57]$ & \\
\hline \multicolumn{6}{|c|}{ Heterogeneity: $T^{2}=0.01, \mathrm{I}^{2}=13.47 \%, \mathrm{H}^{2}=1.16$} \\
\hline \multicolumn{6}{|c|}{ Test of $\theta_{i}=\theta_{i}: Q(9)=9.32, p=0.41$} \\
\hline \multicolumn{6}{|c|}{ Test of $\theta=0: z=3.67, p=0.00$} \\
\hline .00 & & & 0.5 & & \\
\hline
\end{tabular}

Random-effects REML model

Source: own authorship.

Figure 3. Meta-analysis of observational studies on occupational stress and cardiovascular diseases (subgroup analysis).

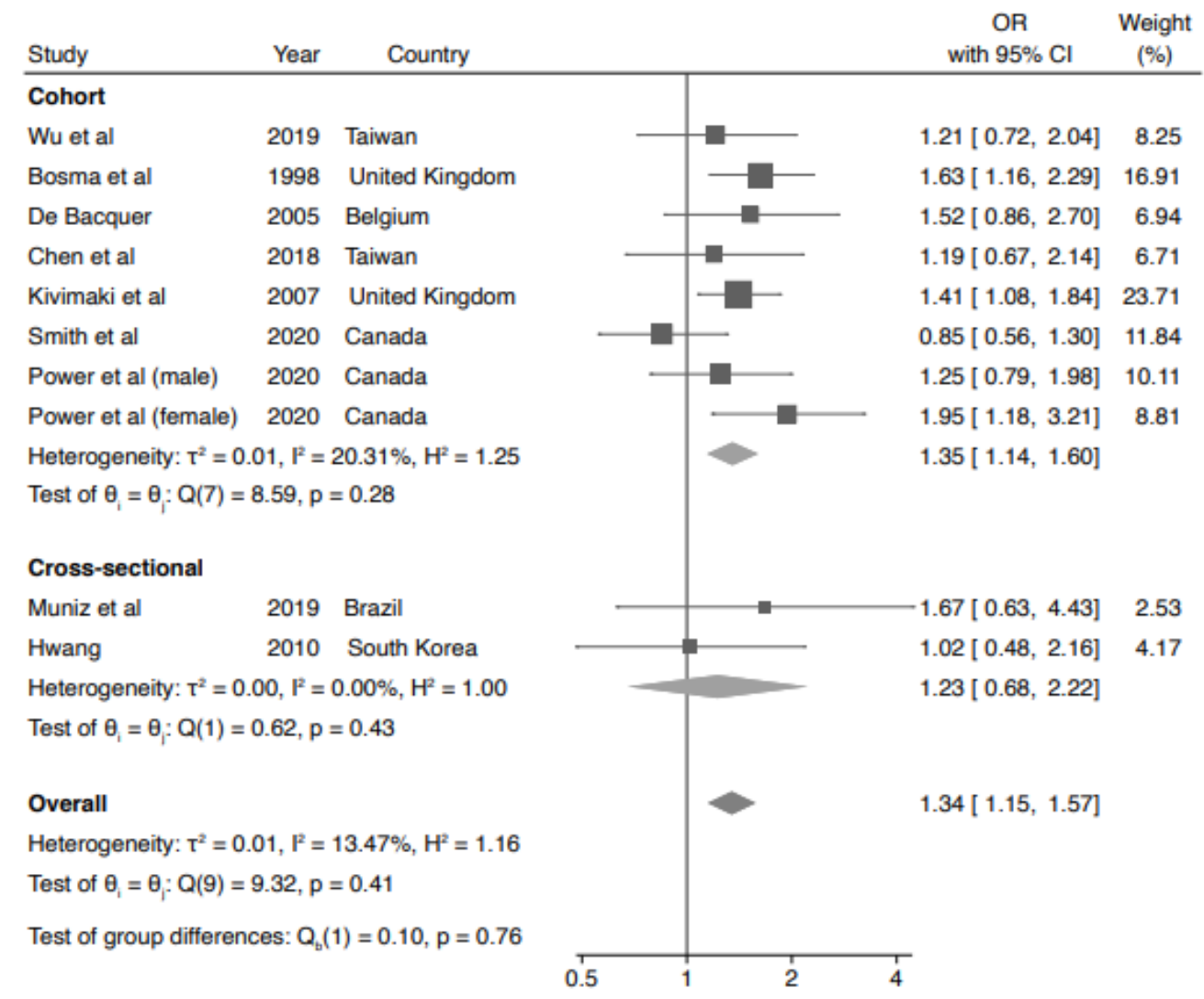

Random-effects REML model 
Metabolic syndrome. The results of the meta-analysis, including five studies, identified a $175 \%$ greater chance of workers with high occupational stress levels having MS, compared to workers with low stress, and this result was statistically significant (OR 2.75; 95\%CI 1.97-3.83; I² 20.49\%). Through subgroup analysis, this relationship was stronger in crosssectional (OR 3.30; 95\%CI 1.51-7.20) than in cohort studies (OR 2.43; 95\%CI 1.70-3.47) (Figure 4).

Figure 4. Meta-analysis of observational studies on occupational stress and metabolic syndrome.

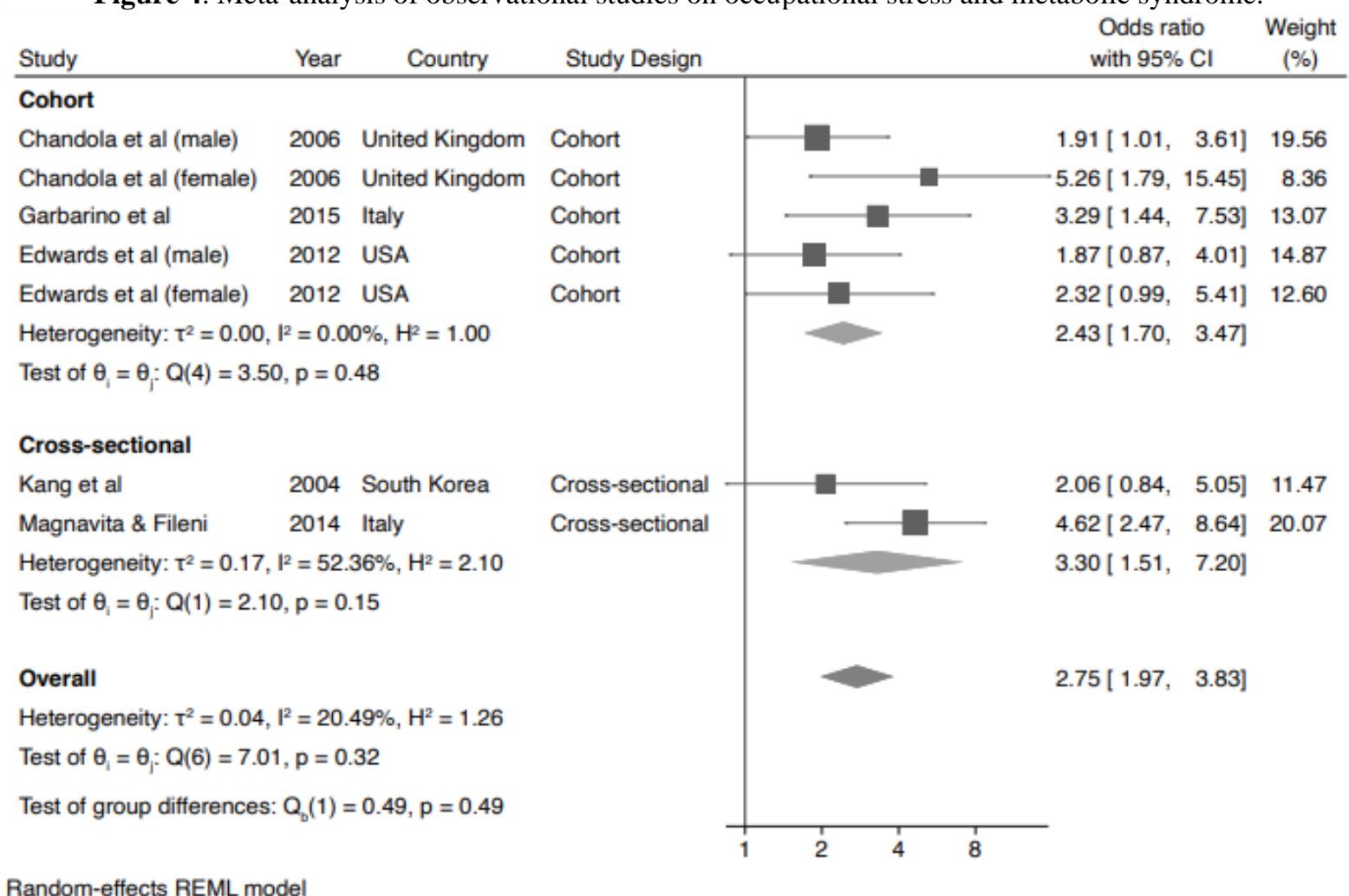

Source: Own authorship.

Dyslipidemias. The dyslipidemia meta-analysis, which adopted OR as a summary measure, included six studies, and did not identify an association between high occupational stress levels and dyslipidemias in adult workers (OR 2.11; 95\%CI 0.98-4.57; $\mathrm{I}^{2}$ 95.81\%) (Figure 5). In the sensitivity analysis, the withdrawal of studies by Aboa-Éboulé et al. (2007), Cho et al. (2005), and Garbarino et al. (2015) - which presented discrepant OR values - did not statistically change the measure of association (OR 1.19; 95\% CI 0.98-1.44; $\mathrm{I}^{2} 49.10 \%$ ) (Figure 6). For the meta-analysis using the beta coefficient as a summary measure, a positive and significant association was identified between occupational stress and dyslipidemias (Coeff. Beta 2.06; 95\%CI 0.68-3.44; $\mathrm{I}^{2} 0.00 \%$ ) (Figure 7). By excluding the Kang et al. (2004) study, the only cross-sectional study that presented very high beta values, the association between exposure and outcome was maintained (Coeff. Beta 1.96; 95\%CI 0.57-3.34; $\mathrm{I}^{2}$ $0.00 \%$ ) (Figure 8). 
Figure 5. Meta-analysis of observational studies on occupational stress and dyslipidemias, considering odds ratio as summary measure.

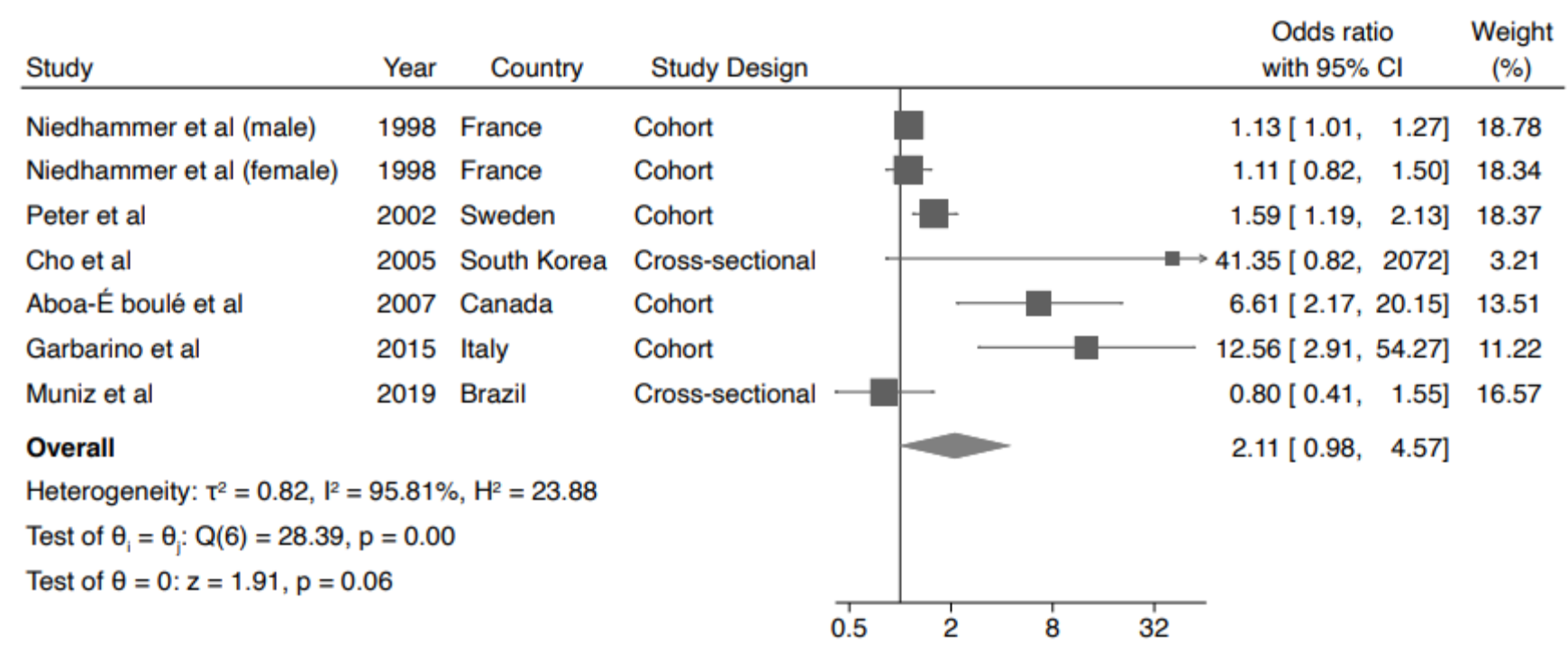

Random-effects REML model

Source: Own authorship.

Figure 6. Meta-analysis of observational studies on occupational stress and dyslipidemias, considering odds ratio as summary measure (after sensibility analysis).

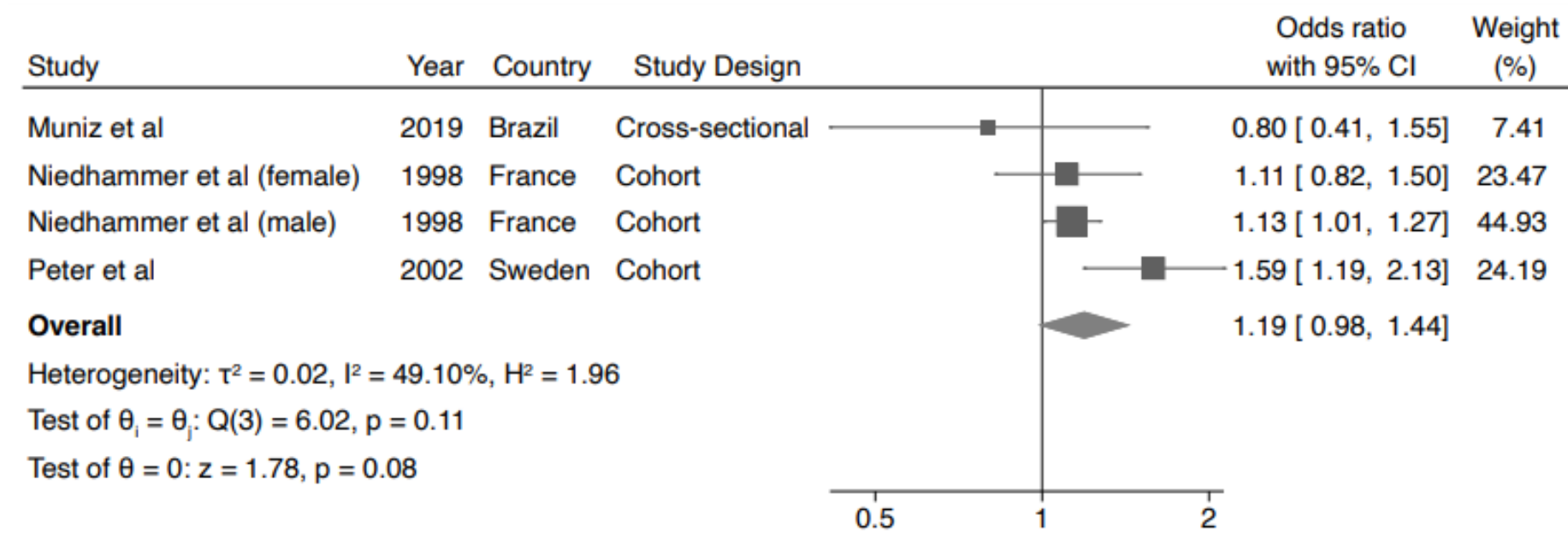

\section{Random-effects REML model}

Source: Own authorship. 
Figure 7. Meta-analysis of observational studies on occupational stress and dyslipidemias, considering beta coefficient as summary measure.

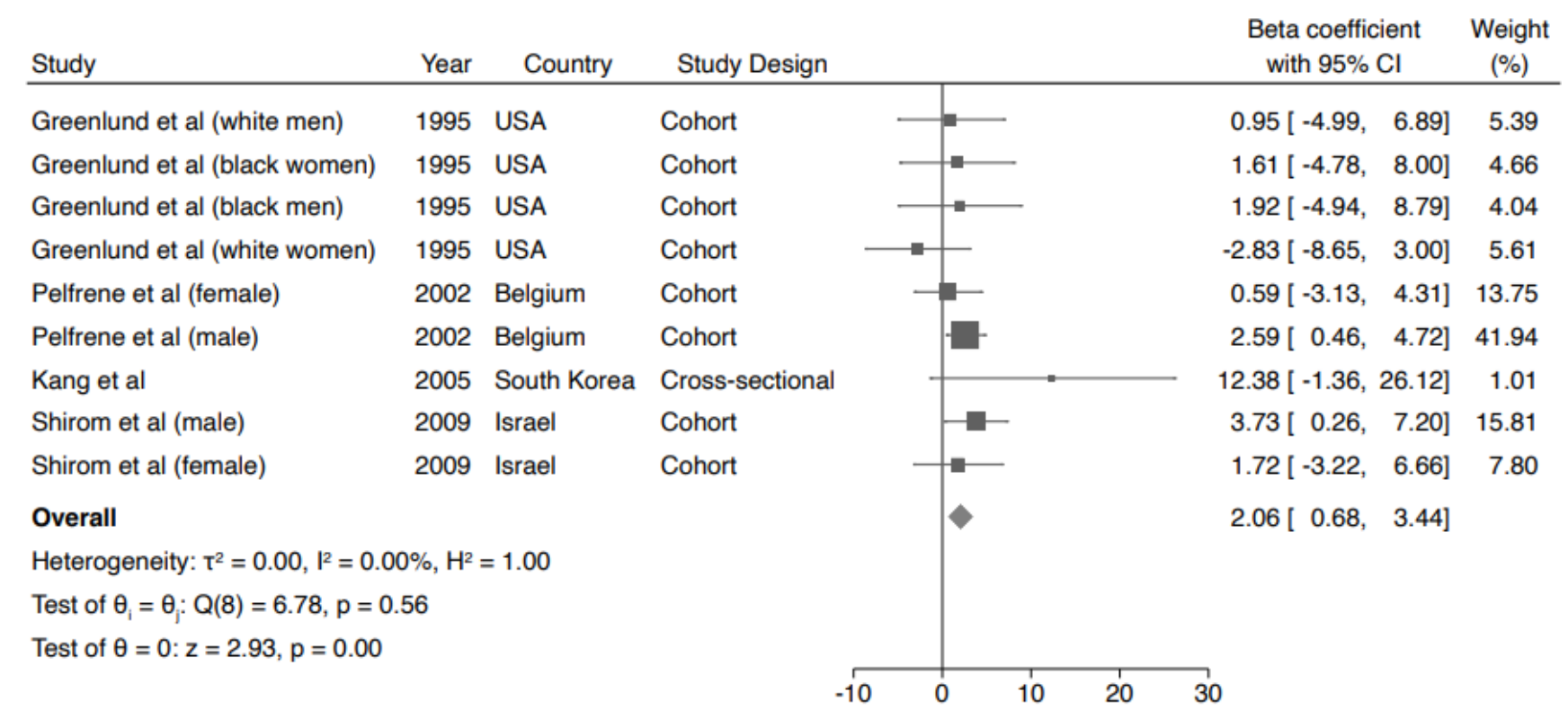

Random-effects REML model

Source: Own authorship.

Figure 8. Meta-analysis of observational studies on occupational stress and dyslipidemias, considering beta coefficient as summary measure (after sensibility analysis).

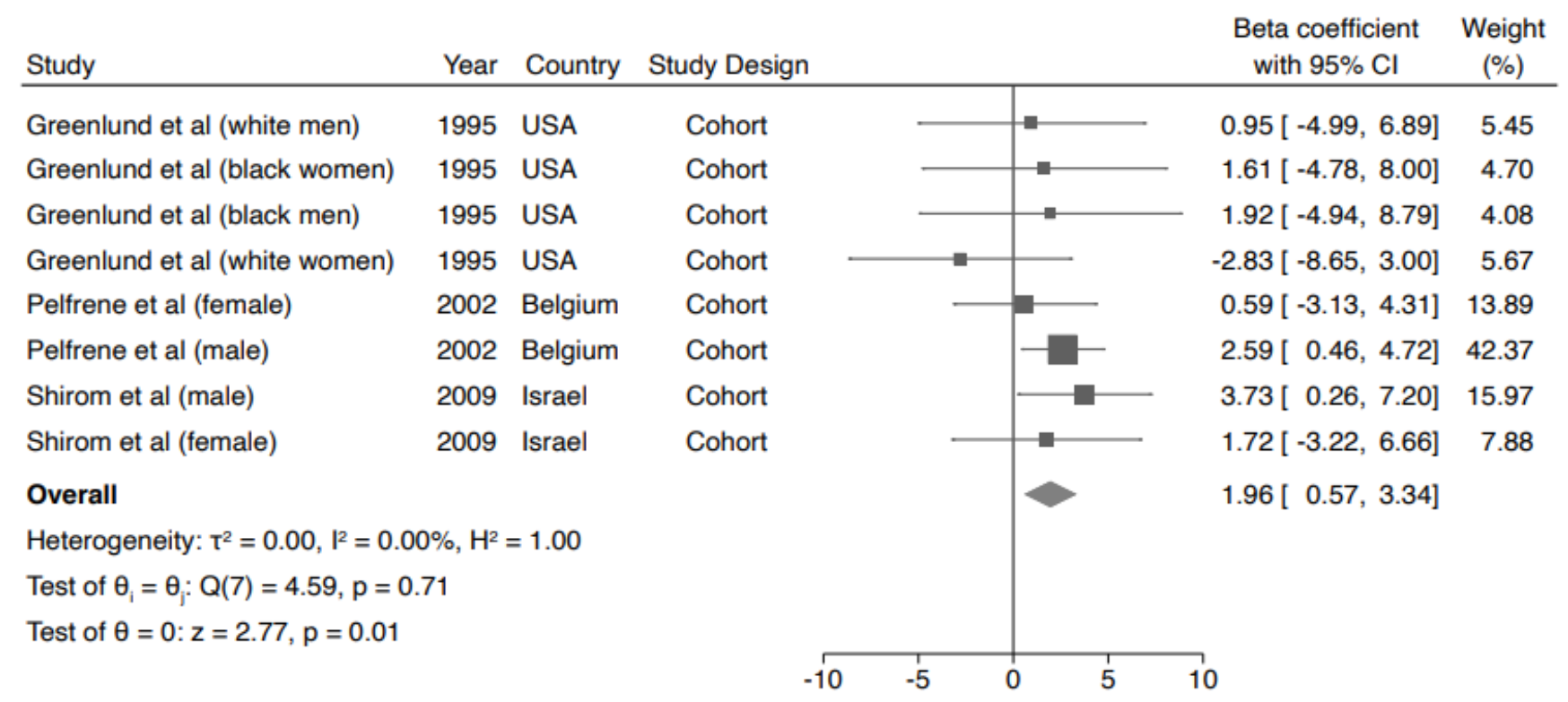

Random-effects REML model

Source: Own authorship.

Obesity. The results of the BMI meta-analysis, which included fourteen studies, did not identify an association between high occupational stress levels and BMI in adult workers (OR 1.08; 95\%CI 0.99-1.17; $\mathrm{I}^{2}$ 96.67\%) (Figure 9). Yet, on the subgroup analysis, a positive relationship between job strain and BMI was observed when considering only the cohort studies (OR 1.10; 95\%CI 1.10-1.21; I² 96.37\%) (Figure 10). However, there was evidence of effect of small studies (Egger's 
test p: 0.0163), suggesting publication bias. Regarding the WC meta-analysis, which included four studies, there was no association between occupational stress and central obesity (OR 0.78; 95\% CI 0.39-1.58; I² 93.37\%) (Figure 11).

Figure 9. Meta-analysis of cohort studies on occupational stress and obesity according to body mass index.

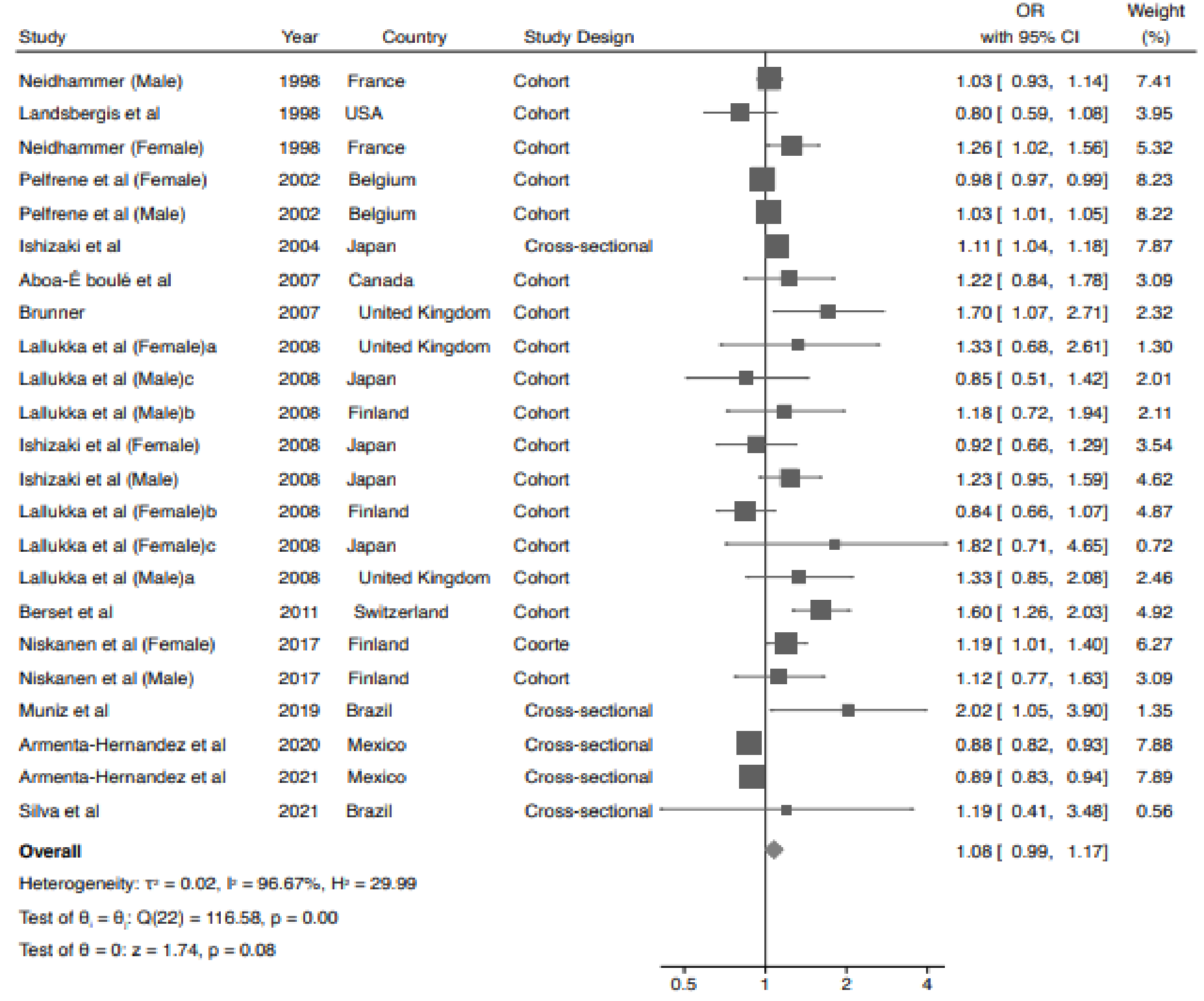

Random-effects REML model

Source: Own authorship. 
Figure 10. Meta-analysis of cohort studies on occupational stress and obesity according to body mass index (after sensibility analysis).

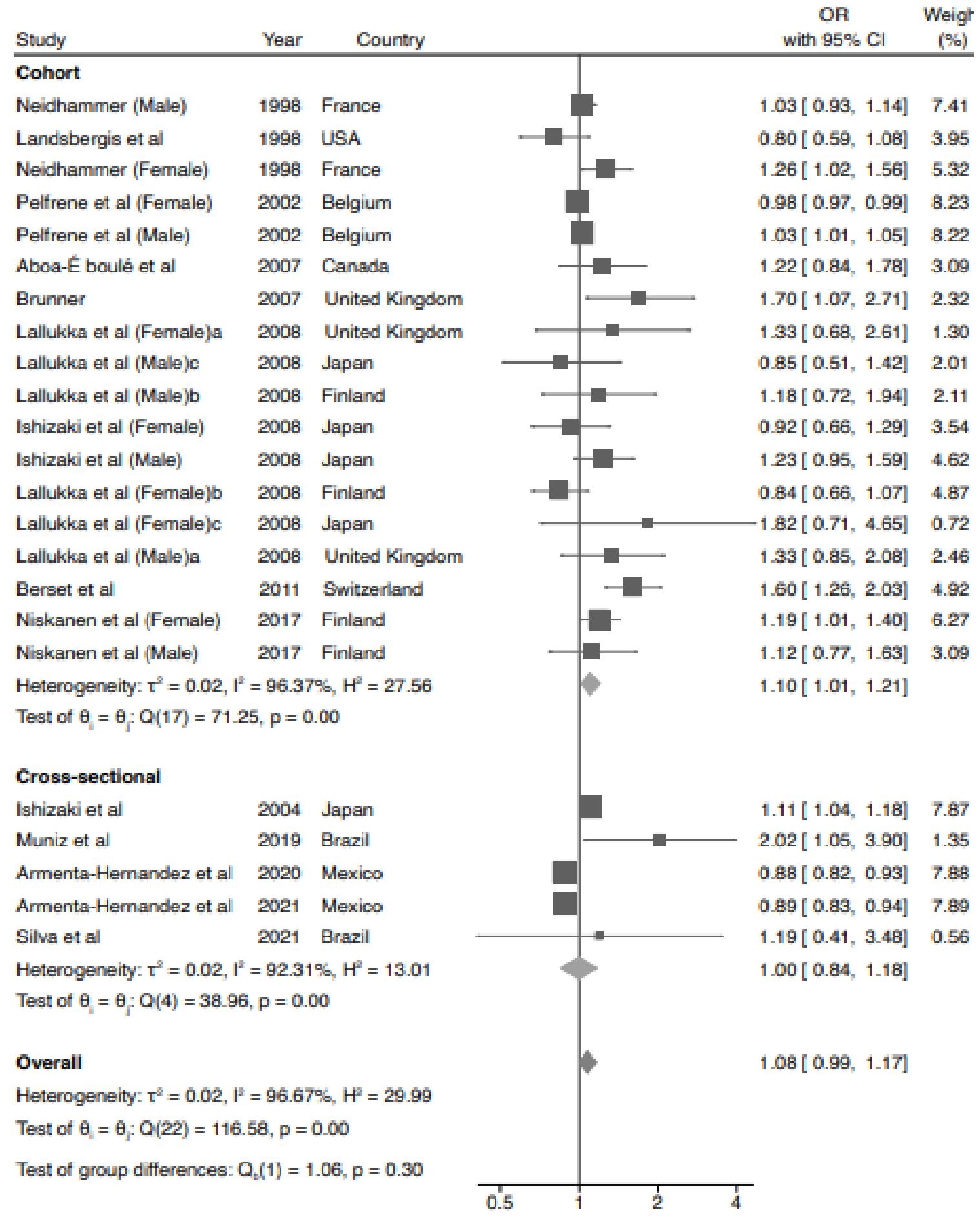

Random-effects REML model 
Figure 11. Meta-analysis of cohort studies on occupational stress and obesity according to waist circumference.

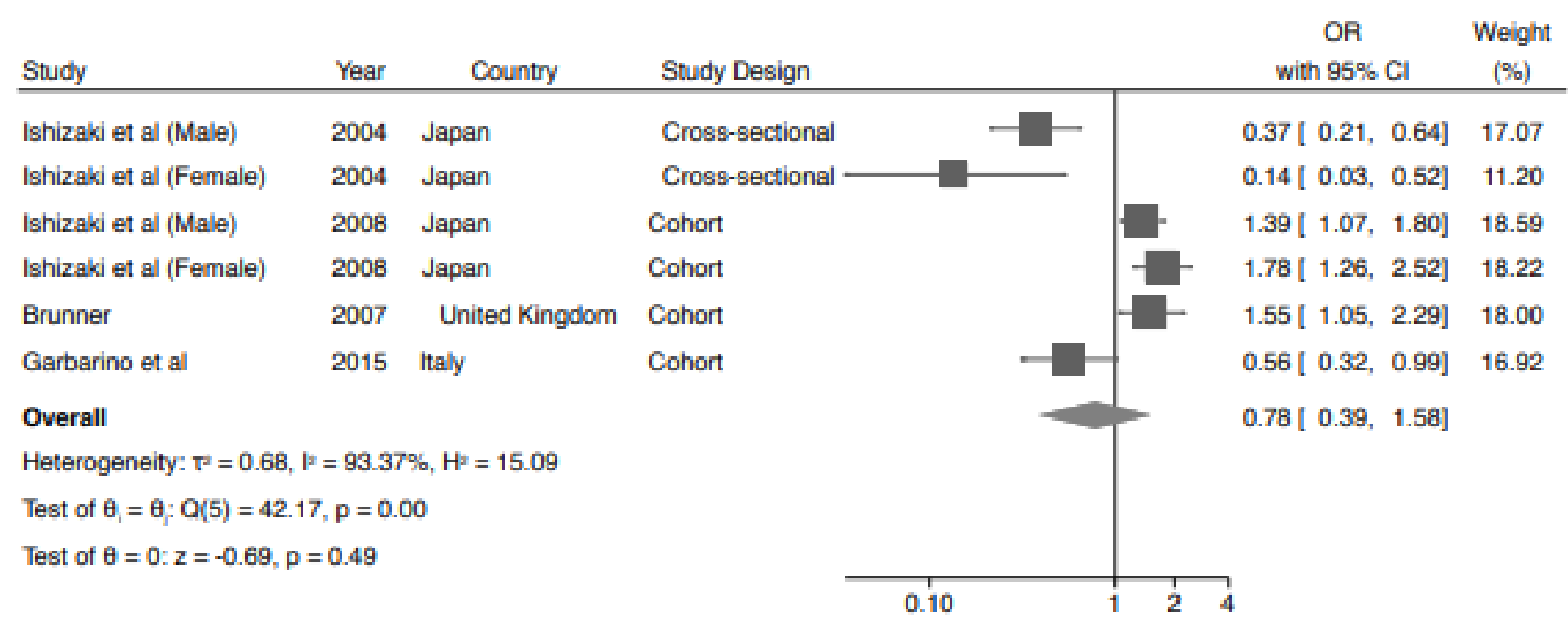

Random-effects REML model

Source: Own authorship.

\section{Risk of bias}

Regarding the risk of bias assessment of the studies considered in this study, thirty-three were classified as having a low risk of bias, while only nine were divided between moderate and high risk (Table 2 and 3). The main reasons for classifying the Netterstrom et al. (1991), Kang et al. (2004), Cho et al. (2005), Evolahti (2012), Berset et al. (2011), Magnavita and Fineli (2014), Muniz et al. (2019), and Armenta-Hernandez et al. $(2020 ; 2021)$ studies in moderate or high risk of bias were mainly due to the sample selection, definition and analysis comparability process, and analysis outcome. In the first case, the authors did not detail the participants' inclusion/exclusion criteria, in the second, there was no clarity regarding consideration of important confounding and effect-modifying factors in the data analyses, and in the last, there was no evaluation of the impact of the follow-up losses.

\section{Discussion}

Studies evaluating the association between occupational stress and chronic non-communicable diseases, specifically CVD, SM, dyslipidemias, and obesity, were included in this systematic review and meta-analysis. The results reveal evidence that, according to the Demand-Control Model, occupational stress is associated with greater chances of occurrence of these diseases.

With regards to the study design, twelve are cross-sectional studies, and fourteen are prospective cohorts. According to Gilbert-Ouimet et al. (2014), prospective studies are more appropriate than cross-sectional studies to assess chronic diseases that form cardiovascular risk, since cardiovascular changes can take years to develop. Thus, prospective studies have a better advantage, by allowing a time interval between exposure and measurement of the outcome, minimizing the causality bias.

It is important to notice that amongst the studies included in this review, there was a greater proportion of prospective studies that demonstrated the harmful effects of occupational stress on workers' health (15/22) compared to cross-sectional studies (8/20). This was also verified by separately analyzing each outcome, with exception of obesity (significant effect in 3/7 cohort studies versus $1 / 3$ cross-sectional studies for CVD, $3 / 3$ versus $1 / 2$ for MS, 5/7 versus 2/8 for dyslipidemias, and 4/9 versus $8 / 13$ for obesity). The more consistent effect of the cohort studies was confirmed by the sensitivity and subgroup analyses, since the exclusion of cross-sectional studies remained the significant association in three out of four meta-analyses 
performed and became significant for the BMI meta-analysis.

As demonstrated by this and other meta-analyses (Gilbert-Ouimet et al., 2014; Sui et al., 2016; Sara et al., 2018; Duchaine et al., 2020), job strain can negatively affect workers' health. Considering the cardiovascular risk components, the main mechanisms involved in this process refer to activation of the hypothalamic-pituitary-adrenal (HPA) and sympatheticmedulla-adrenal (SMA) axes. The HPA axis acts through cortisol action, and the SMA axis through the action of cytokines and inflammatory proteins (Almadi et al., 2013).

HPA axis activation, also the sympathetic nervous system, by occupational stress, promotes sympathetic hormones and glucocorticoid release, especially cortisol, which, in turn, stimulates the production of glucose by hepatocytes, culminating in hyperglycemia. Another important action of this hormone is the inhibition of insulin secretion by pancreatic beta cells and glucose uptake by muscles, which results in glucose intolerance and insulin resistance. Cortisol also stimulates triglyceride lipolysis in adipocytes, increasing the level of circulating fatty acids in plasma (Sui et al., 2016; Almadi et al., 2013); all these alterations are implicated in the etiology of diseases, such as type 2 diabetes, dyslipidemias, visceral obesity, metabolic syndrome and, consequently, cardiovascular diseases.

With regards to the SMA axis, its activation promotes the release of cytokines and pro-inflammatory proteins, such as C-reactive protein (CRP). CRP can interfere with the signaling pathways of glucocorticoids and insulin, resulting in increased plasma cortisol levels and, consequently, insulin resistance, and other changes related to metabolic syndrome. On the other hand, pro-inflammatory cytokines act to increase the plasma concentration of non-esterified fatty acids through the inhibition of lipoprotein lipase, which contributes to the occurrence of dyslipidemias (Almadi et al., 2013).

Another important aspect to be evaluated is changes to workers' lifestyles, such as inappropriate eating behavior, a sedentary lifestyle, smoking, and alcohol consumption, since all of these may arise from occupational stress, and may increase the risk of developing chronic diseases, acting as an indirect mechanism (Sui et al., 2016; Lallukka et al., 2008; Sara et al., 2018; Kivimäki \& Kawachi, 2015).

We also needed to observe the criteria for assessing occupational stress. In this review, we chose to only consider studies that used the Demand-Control model to diagnose work-related stress, since uniformity in the measurement of psychosocial work factors is recommended for better comparability between studies (Gilbert-Ouimet et al., 2014). Furthermore, this model was taken as a reference.

The Demand-Control model has the coexistence of large psychological demands and low control in the work process as generators of high strain (occupational stress) as the theoretical assumption. The extent of an individual's discretion in the face of work demands modulates the expression of stress. Therefore, this is a stress management model based on the work environment, if no action can be taken, or if the worker needs to resign, due to low control at work, there is a manifestation of stress as mental tension (Karasek, 1979), and/or its somatization in other types of diseases.

It is known that this model was initially developed to describe psychosocial factors that affect mental health (Karasek, 1979). However, its suitability for modeling the association of stress with chronic diseases, such as cardiovascular risk factors, is well established in literature (Gilbert-Ouimet et al., 2014; Sui et al., 2016; Sara et al., 2018; Kivimäki et al., 2015). According to Kivimäki and Kawachi (2015), several prospective studies investigated this relationship, and their findings, are described in narrative reviews and their meta-analysis: the combined relative risk of coronary heart disease in the studies they evaluated was 1.34 (95\% CI 1.18 -1.51) times higher for workers with occupational stress, when compared to those free from stress. This result agrees with the present meta-analysis, whose OR was also 1.34. However, as a differential of this work, there is the assessment of morbidity from cardiovascular diseases, excluding studies that considered deaths from coronary events.

Another relevant factor of this review and meta-analysis concerns the assessment of the risk of bias in the studies: only six were classified as having a moderate or high risk of bias. Kang et al. (2004), Cho et al. (2005), Evolathi (2012), Berset 
et al. (2011), Magnavita and Fileni (2014), and Armenta-Hernandez et al. (2020; 2021) did not detail the participant inclusion/exclusion criteria in their studies, which may suggest selection bias. According to Gilbert-Ouimet et al. (2014), selection bias can be introduced in a study when participants and non-participants differ in their vulnerability to exposure and outcome, and this difference can lead to an under- or overestimation of the true effects between them (exposure and outcome). However, the participants of these four studies represent only $1.06 \%$ of the total number in this review, which minimizes the risk of compromising the quality of the results of this study.

With regards to studies by Netterstrom et al. (1991) and Muniz et al. (2019), there was no clarity regarding the consideration of confounding factors in data analyses, indicating a confounding bias. Thus, it is not possible to exclude the possibility that unadjusted confounding factors affected the association with the outcomes, which may have an impact on the result presented by these authors. However, it is believed that this impact is minimized in the current study, since only the study by Muniz et al. (2019) was considered, with little weight, in the meta-analyses for CVD and dyslipidemias (2.53\% and $7.41 \%$ (after sensitivity analysis), respectively). The study by Berset et al. (2011) did not assess the impact of the follow-up losses, which could compromise the reliability of their results. It is also important to highlight that, despite these limitations, most of the studies included in this review presented a low risk of bias, indicating that the data analyzed here is reliable, guaranteeing the quality of the results of the meta-analyses, and the conclusion of this study.

Besides that, all the methodological steps, according to the PRISMA protocol, were followed during this systematic review process in order to avoid bias. The survey, data extraction, and risk of bias assessment were carried out independently by two researchers. Important databases were consulted in the bibliographic search to obtain the largest possible number of published studies on the subject (including gray literature). Reference lists of the selected studies were also evaluated for additional study inclusion. There were no restrictions on the time, place and/or language of the studies, nor was there any indication of publication bias.

\section{Conclusion}

This work identified that individuals with occupational stress are more likely to develop CVD and MS. However, regarding obesity and dyslipidemias, when considering the OR as a summary measure, there were no significant associations. Furthermore, the results of these meta-analyses need to be interpreted with caution, due to the high heterogeneity of both models, and the possible publication bias of the BMI model; however, the high methodological quality applied in the studies reinforces the validity of the results presented here.

Therefore, considering the evidence linking occupational stress with chronic non-communicable diseases, it is relevant to develop actions that alleviate stress at work, so as to provide a better quality of life for workers. Furthermore, further studies that combine clinical trial design and chronic diseases should be encouraged, to assess the role of occupational stress in their etiology.

\section{Acknowledgments}

The authors thank the Covidence ${ }^{\circledR}$ team for kindly providing a free program license to carry out this review.

This research received no specific grant from any funding agency, commercial or not-for-profit sectors.

L.G.C. and P. R. F. C. formulated the research question. L.G.C., P. R. F. C. and J. C. D. P. designed the study, conducted the study and analyzed the data. L. G. C. and C.R.L. extracted the data and evaluated the risk of bias. L.G.C., P.R.F.C., S.K., and R.d.C.C.d.A.A. discussed the results and wrote the paper. All of the authors contributed to the revision of the manuscript and read and approved the final version. 
None of the authors have any conflicts of interest to declare.

\section{References}

Aboa-Éboulé, C., Brisson, C., Maunsell, E. et al. (2007). Job Strain and Risk of Acute Recurrent Coronary Heart Disease Events. JAMA, 298:14 (Reprinted). https://doi:10.1001/jama.298.14.1652

Almadi, T., Carthers, I., \& Chow, CM. (2013). Associations among work-related stress, cortisol, inflammation, and metabolic syndrome. Psychophysiology, 50:821-30. https://doi:10.1111/psyp. 12069

Araújo, T. M., Graça, C. C., \& Araújo, E. (2003). Estresse ocupacional e saúde: contribuições do Modelo Demanda-Controle. Cien Saude Colet, 8(4):9911003. https://doi:10.1590/S1413-81232003000400021

Armenta-Hernandez, O. D., Maldonado-Macías, A. A., Baez-Lopez, Y. A. et al. (2021). Impact of job strain and being overweight on middle and senior managers from the manufacturing sector in the Mexican industry. Work, 69(3):1027-40. https://doi:10.3233/WOR-213533

Armenta-Hernandez, O. D., Maldonado-Macías, A. A., Solís, M. O. et al. (2020). Effects of job content and physical activity on body mass index among obese managers of the Mexican manufacturing industry. Int J Environ Res Public Health, 17:3969. https://doi:10.3390/ijerph17113969

Berset, M., Semmer, N. K., Elfering, A. et al. (2011). Does stress at work make you gain weight? A two-year longitudinal study. Scand J Work Environ Health, 37(1):45-53. https://doi:10.5271/sjweh.3089

Bosma, H., Peter, R., Siegrist, J. et al. (1998). Two alternative job stress models and the risk of coronary heart disease. Am J Public Health, 88(1):68-74. https://doi:10.2105/ajph.88.1.68

Brunner, E. J., Chandola, T., \& Marmot, M. G. (2007). Prospective effect of job strain on general and central obesity in the Whitehall II study. Am $J$ Epidemiol, 165(7):828-37. https://doi:10.1093/aje/kwk058

Chandola, T., Brunner, E., Marmot, M. (2006). Chronic stress at work and the metabolic syndrome: prospective study. BMJ, 332:521. https://doi:10.1136/bmj.38693.435301.80

Chen, W. L., Wang, C. C., Chiang, S. T. et al. (2018). The impact of occupational psychological hazards and metabolic syndrome on the 8-year risk of cardiovascular diseases - a longitudinal study. PLOS ONE, 13(8):e0202977. https://doi.org/10.1371/journal

Cho, E. Y., Lee, Y. W., \& Kim, H. S. (2005). The effect of job stress and lifestyle on blood lipid levels in male aircrew personnel. J Korean Acad Nurs, 35(4):672-679. https://doi:10.4040/JKAN.2005.35.4.672

Creedy, D. K., Sidebotham, M., Gamble, J. et al. (2017). Prevalence of burnout, depression, anxiety and stress in Australian midwives: a cross-sectional survey. BMC Pregnancy and Childbirth, 17:13. https://doi:10.1186/s12884-016-1212-5

De Bacquer, D., Pelfrene, E., Clays, E. et al. (2005). Perceived job stress and incidence of coronary events: 3-year follow-up of the belgian job stress project cohort. Am J Epidemiol, 161(5):434-441. https://doi:10.1093/aje/kwi040

Deeks, J. J., Higgins, J. P. T., \& Altman, D. G (editors). (2019). Analysing data and undertaking meta-analyses. In: Higgins JPT, Thomas J, Chandler J, et al., (editors). Cochrane Handbook for Systematic Reviews of Interventions version 6.0 (updated July 2019). Barcelona: Centro Cochrane Iberoamericano. Available at: www.training.cochrane.org/handbook

Duchaine, C. S., Aubé, K., Gilbert-Ouimet, M. et al. (2020). Psychosocial stressors at work and the risk of sickness absence due to a diagnosed mental disorder: a systematic review and meta-analysis. JAMA Psychiatry, 77(8):842-51. https://doi:10.1001/jamapsychiatry.2020.0322

Edwards, E. M., Stuver, S. O., Heeren, T. C. et al. (2012). Job strain and incident metabolic syndrome over 5 years of follow-up. JOEM, 54:1447-52. https://doi:10.1097/JOM.0b013e3182783f27

Evolahti, A. (2012). Women, work and stress. Department of clinical neuroscience division of psychology Karolinska Institutet, Stockholm, Sweden. Stockholm.

Filha, M. M. T. Costa, M. A. S. \& Guilam, M. C. R. (2013). Estresse ocupacional e autoavaliação de saúde entre profissionais de enfermagem. Rev Latino-Am Enfermagem, 21(2): [09telas]. https://doi:10.1590/S0104-11692013000200002

Garbarino, S., \& Magnavita, N. (2015). Work stress and metabolic syndrome in police officers. A prospective study. PLoS ONE, 10(12): e0144318. https://doi:10.1371/journal.pone.0144318

Gilbert-Ouimet, M., Trudel, X., Brisson, C. et al. (2014). Adverse effects of psychosocial work factors on blood pressure: systematic review of studies on demand-control-support and effort-reward imbalance models. Scand J Work Environ Health, 40(2):109-32. https://doi:10.5271/sjweh.3390

Grant, R. L. (2014). Converting an odds ratio to a range of plausible relative risks for better communication of research findings. $B M J$, 348 : f7450. https://doi:10.1136/bmj.f7450

Greenlund, K. J., Liu, K., Knox, S. et al. (1995). Psychosocial work characteristics and cardiovascular disease risk factors in young adults: the cardia study. Soc Sci Med, 41(5):717-723. https://doi:10.1016/0277-9536(94)00385-7

Hellerstedt, W. L., \& Jeffery, RW. (1997). The association of job strain and health behaviours in men and women. Int J Epidemiol, 26(3):575-83. https://doi:10.1093/ije/26.3.575 
Higgins, J. P. T, Thomas, J., Chandler, J. et al. (editors). (2021). Cochrane handbook for systematic reviews of interventions version 6.2 (updated February 2021). Cochrane. Available at: www.training.cochrane.org/handbook

Hwang, W. J. (2010). Cardiovascular disease in korean blue-collar workers: actual risk, risk perception, and risk reduction behavior. Dissertation. University of California, San Francisco.

Ishizaki, M., Nakagawa, H., Honda, R. et al. (2004). The influence of work characteristics on body mass index and waist to hip ratio in Japanese employees. Ind Health, 42(1):41-9. https://doi:10.2486/indhealth.42.41

Ishizaki, M., Nakagawa, H., Morikawa, Y. et al. (2008). Influence of job strain on changes in body mass index and waist circumference - 6-year longitudinal study. Scand J Work Environ Health, 34(4):288-96. https://doi:10.5271/sjweh.1267

Jääskeläinen, A., Kaila-Kangas, L., Leino-Arjas, P. et al. (2015). Association between occupational psychosocial factors and waist circumference is modified by diet among men. Eur J Clin Nutr, 69(9):1053-9. https://doi:10.1038/ejen.2015.59

Juvanhol, L. L., Melo, E. C. P., Carvalho, M. S. et al. (2017). Job strain and casual blood pressure distribution: looking beyond the adjusted mean and taking gender, age, and use of antihypertensives into account. Results from ELSA-Brasil. Int J Everom Res Public Health, 14(4):451. https://doi:10.3390/ijerph14040451

Kang, M. G., Koh, S. B., Cha, B. S. et al. (2004). Association between job stress on heart rate variability and metabolic syndrome in shipyard male workers. Yonsei Med J, 45(5):838-846. https://doi:10.3349/ymj.2004.45.5.838

Kang, M. G., Koh, S. B., Cha, B. S. et al. (2005). Job stress and cardiovascular risk factors in male workers. Prev Med, 40:583-8. https://doi:10.1016/j.ypmed.2004.07.018

Karasek, R. (1979). Job demands, job decision latitude, and mental strain: implications for job redesign. Adm Sci Quarterly, 24:285-308. https://doi:10.2307/2392498

Kawakami, N., Haratani, T., \& Araki, S. (1998). Job strain and arterial blood pressure, serum cholesterol, and smoking as risk factors for coronary heart disease in Japan. Int Arch Occup Environ Health, 71:429-432. https://doi:10.1007/s004200050302

Kivimäki, M., \& Kawachi I. (2015). Work stress as a risk factor for cardiovascular disease. Curr Cardiol Rep, 17(9):74. https://doi:10.1007/s11886-015-06308

Kivimäki, M., Head, J., Ferrie, J. E. et al. (2007). Hypertension is not the link between job strain and coronary heart disease in the Whitehall II study. Am J Hypertens, 20:1146-1153. https://doi:10.1016/j.amjhyper.2007.06.006

Kivimäki, M., Singh-Manoux, A., Nyberg, S. et al. (2015). Job strain and risk of obesity: systematic review and meta-analysis of cohort studies. Int J Obes (Lond). 39(11):1597-600. https://doi:10.1038/ijo.2015.103

Lallukka, T., Lahelma, E., Rahkonen, O. et al. (2008). Associations of job strain and working overtime with adverse health behaviors and obesity: evidence from the Whitehall II Study, Helsinki Health Study, and the Japanese Civil Servants Study. Soc Sci Med, 66:1681e1698. https://doi:10.1016/j.socscimed.2007.12.027

Landsbergis, P. A., Schnall, P. L. et al. (1998). Job strain and health behaviors: results of a prospective study. Am J Health Promot, 12(4):237-245. https://doi:10.4278/0890-1171-12.4.237

Li, W., Zhang, J. Q., Sun, J. et al. (2007). Job stress related to glyco-lipid allostatic load, adiponectin and visfatin. Stress Health, 23:257-66. https://doi:10.1002/smi.1145

Magnavita, N., \& Fileni, A. (2014). Work stress and metabolic syndrome in radiologists: first evidence. Radiol Med, 119(2):142-8. https://doi:10.1007/s11547013-0329-0

Muniz, D. D., Siqueira, K. S., Cornell, C. T. et al. (2019). Ideal cardiovascular health and job strain: a cross-sectional study from the Amazon Basin. Arq Bras Cardiol, 112(3):260-268. https://doi:10.5935/abc.20190005

Netterstrom, B., Kristensen, T. S., Damsgaard, M. T. et al. (1991). Job strain and cardiovascular risk factors: a cross sectional study of employed Danish men and women. Br J of Ind Med, 48:684-689. https://doi:10.1136/oem.48.10.684

Niedhammer, I., Goldberg, M., Leclerc, A. et al. (1998). Psychosocial work environment and cardiovascular risk factors in an occupational cohort in France. $J$ Epidemiol Community Health, 52:93-100. https://doi:10.1136/jech.52.2.93

Niskanen, R., Holstila, A., Rahkonen, O. et al. (2017). Changes in working conditions and major weight gain among normal- and overweight midlife employees. Scand J Work Environ Health, 43(6):587-94. https://doi:10.5271/sjweh.3678

Nomura, K., Nakao, M., Karita, K. et al. (2005). Association between work-related psychological stress and arterial stiffness measured by brachial-ankle pulse-wave velocity in young Japanese males from an information service company. Scand J Work Environ Health, 31(5):352-9. https://doi:10.5271/sjweh.918

Ostry, A. S., Radi, S., Louie, A. M. et al. (2006). Psychosocial and other working conditions in relation to body mass index in a representative sample of Australian workers. BMC Public Health, 6:53. https://doi:10.1186/1471-2458-6-53

Page, M. J., McKenzie, J. E., Bossuyt, P. M. et al. (2021). The PRISMA 2020 statement: an updated guideline for reporting systematic reviews. BMJ, 372(71):1-9. https://doi:10.1136/bmj.n71

Pelfrene, E., De Backer, G., Mak, R. et al. (2002). Job stress and cardiovascular risk factors Results from the BELSTRESS study. Arch Public Health, 60:245268. 
Research, Society and Development, v. 11, n. 3, e23111326449, 2022

(CC BY 4.0) | ISSN 2525-3409 | DOI: http://dx.doi.org/10.33448/rsd-v11i3.26449

Pelfrene, E., Leynen, F., Mak, R. P. et al. (2003). Relationship of perceived job stress to total coronary risk in a cohort of working men and women in Belgium. Eur J Prev Cardiol, 10(5):345-354. https://doi:10.1097/01.hjr.0000095048.46631.f0

Peter, R., Alfredsson, L., Hammar, N. et al. (2002). Job strain, effort-reward imbalance, and coronary risk factors-complementary job stress models in risk estimation? International Congress Series, 1241:165-71.

Power, N., Deschênes, S. S., Ferri, F. et al. (2020). Job strain and the incidence of heart diseases: a prospective community study in Quebec, Canada. $J$ Psychosom Res, 139:110268. https://doi:10.1016/j.jpsychores.2020.110268

Riese, H., Doornen, L. J. P. V., Houtman, I. L. D. et al. (2000). Job strain and risk indicators for cardiovascular disease in young female nurses. Health Psychol, 19(5):429-140. https://doi:I0.I037Irc2784t33.i9.5.429

Rothman, K. J., Greenland, S., \& Lash, T. L. (2008). Fundamentals of epidemiologic data analysis. In: Modern Epidemiology.

Sancini, A., Ricci, S., Tomei, F, et al. (2017). Work-related stress and blood glucose levels. Ann Ig, 29(2):123-33. https://doi:10.7416/ai.2017.2139

Santos, I. E. R., Vargas, M. M., \& Rei, F. P. (2014). Estressores laborais em agentes comunitários de saúde. Rev Psicol Organ Trab, 14(3):324-35.

Sara, J. D., Prasad, M., Eleid, M. F. et al. (2018) A. Association between work-related stress and coronary heart disease: a review of prospective studies through the job strain, effort-reward balance, and organizational justice models. J Am Heart Assoc, 7(9):1-15. https://doi:10.1161/JAHA.117.008073

Shirom, A., Melamed, S., Rogowski, O. et al. (2009). Workload, control, and social support effects on serum lipids: a longitudinal study among apparently healthy employed adults. J Occup Health Psychol, 14(4):349-364. https://doi:10.1037/a0015283

Silva, A. M. \& Guimarães, L. A. M. (2016). Occupational stress and quality of life in nursing. Paidéia, 26(63):63-70. https://doi:10.1590/198243272663201608

Silva, J. C., Garcez, A., Cibeira, G. H. et al. (2021). Relationship of work-related stress with obesity among Brazilian female shift workers. Public Health Nutrition, https://doi:10.1017/S1368980020004243

Smith, P., Gilbert-Ouimet, M., Brisson, C. et al. (2021). Examining the relationship between the demand-control model and incident myocardial infarction and congestive heart failure in a representative sample of the employed women and men in Ontario, Canada, over a 15-year period. Can J Public Health, 112(2):280-8. https://doi:10.17269/s41997-020-00378-3

Sousa, V. F. S. \& Araújo, T. C. C. F. (2015). Estresse ocupacional e resiliência entre profissionais de saúde. Psicol Cienc Prof, 35(3):900-15. https://doi:10.1590/1982-370300452014

Sui, H., Sun, N., Zhan, L. et al. (2016). Association between work-related stress and risk for type 2 diabetes: a systematic review and meta-analysis of prospective cohort studies. PLOS ONE, https://doi: 10.1371/journal.pone.0159978

Tonini, E., Broll, A. M., \& Corrêa, E. N. (2013). Avaliação do estado nutricional e hábito alimentar de funcionários de uma instituição de ensino superior do oeste de Santa Catarina. Mundo da Saude, 37(3):268-79. https://doi:10.15343/0104-7809.2013373268279

Viswanathan, M. \& Berkman, N. D. (2012). Development of the RTI item bank on risk of bias and precision of observational studies. J Clin Epidemiol, 65:163-78. https://doi:10.1016/j.jclinepi.2011.05.008

Wu, W. T., Tsai, S. S., Wang, C. C. et al. (2019). Professional driver's job stress and 8-year risk of cardiovascular disease the taiwan bus driver cohort study. Epidemiology, 30:S39-S47. https://doi:10.1097/EDE.0000000000001003 